GRASAS Y ACEITES 68 (3)

July-September 2017, e210

ISSN-L: 0017-3495

doi: http://dx.doi.org/10.3989/gya.0446171

\title{
A study of the differences between trade standards inside and outside Europe
}

\author{
D.L. García-González ${ }^{\mathrm{a}}$, N. Tena ${ }^{\mathrm{a}}$, I. Romero ${ }^{\mathrm{a}}$, R. Aparicio-Ruiz ${ }^{\mathrm{a}}$, M.T. Morales ${ }^{\mathrm{b}}$ and R. Aparicio ${ }^{\mathrm{a}, \bigotimes}$ \\ ${ }^{a}$ Instituto de la Grasa (CSIC), Bdg. 46 Campus University Pablo de Olavide, E-41013 Sevilla, Spain. \\ ${ }^{b}$ Department of Analytical Chemistry, Universidad de Sevilla, Prof. García González, 2, 41012, Seville, Spain. \\ ${ }^{\otimes}$ Corresponding author: aparicio@cica.es
}

Submitted: 19 April 2017; Accepted: 07 June 2017

\begin{abstract}
SUMMARY: The definitions of olive oil categories are common or very similar for all the international regulatory bodies, and in many cases the text is even literally the same. However, the values of some parameters which chemically define the different categories do not have the same degree of agreement. These disagreements mean a difficult task for importers and exporters who have to deal with these differences when they need to defend the quality and genuineness of their product. This work analyzes the differences found when scrutinizing the current trade standards and regulations from a critical viewpoint, with comments and useful tips for improving the current International Olive Council methods when possible, as well as alternatives from non targeted techniques. The values of precision associated with the International Olive Council methods are also examined and the need for re-validating methods to update the analytical quality parameters is discussed.
\end{abstract}

KEYWORDS: Analytical methods; International trade standards; Olive oil; Validation

RESUMEN: Estudio de las diferencias entre las normas comerciales dentro y fuera de Europa. Las definiciones de las categorías de aceite de oliva son comunes o muy similares para todos los organismos reguladores internacionales y, en muchos casos, el texto es incluso literalmente el mismo. Sin embargo, los valores de algunos parámetros que definen químicamente las diferentes categorías no tienen el mismo grado de acuerdo. Estos desacuerdos originan una tarea difícil para los exportadores e importadores que tienen que lidiar con estas diferencias para demostrar la calidad y la autenticidad de su producto. Este trabajo analiza las diferencias encontradas al examinar las normas y regulaciones comerciales actuales desde un punto de vista crítico, con comentarios y sugerencias útiles para mejorar los métodos actuales del Consejo Oleícola Internacional, cuando ha sido posible, así como alternativas de técnicas no dirigidas a analitos específicos. También se examinan los valores de precisión asociados a los métodos del Consejo Oleícola Internacional y se discute la necesidad de volver a validar los métodos para actualizar los parámetros de calidad analítica.

PALABRAS CLAVE: Aceite de oliva; Métodos analiticos; Normas comerciales internacionales; Validación

ORCID ID: García-González DL http://orcid.org/0000-0003-0735-8470, Tena N http://orcid.org/0000-0003-09335192, Romero I http://orcid.org/0000-0003-3811-1577, Aparicio-Ruiz R http://orcid.org/0000-0003-1093-1928, Morales MT http://orcid.org/0000-0001-7058-4433, Aparicio R http://orcid.org/0000-0001-5538-4433

Citation/Cómo citar este artículo: García-González DL, Tena N, Romero I, Aparicio-Ruiz R, Morales MT, Aparicio R. 2017. A study of the differences between trade standards inside and outside Europe. Grasas Aceites 68 (3), e210. http://dx.doi.org/10.3989/gya.0446171

Copyright: (C2017 CSIC. This is an open-access article distributed under the terms of the Creative Commons Attribution (CC-by) Spain 3.0 License. 


\section{INTRODUCTION}

It has been proven that fraud, in one manner or another, has been part of commercial transactions since they were practised in the remote past, and today, with the increase in worldwide commerce, olive oil is considered a vulnerable product in terms of authenticity (Aparicio et al., 2013; EU, 2013). Although it is believed that the ultimate one affected by this dishonest attitude is the consumer, fraud can also spell ruin for many actors in the market like farmers and sellers. Mass media, in fact, do not usually distinguish among food actors that intentionally carry out this illegal and dishonest activity and those that are simply affected by a punctual non intentional fault in quality control. Thus, the entire foodstuff market is covered with doubts about its authenticity when mass media publicize news on fraud, with the real risk that consumers might decide not to consume the food any more. Normally, potential frauds described in olive oil do not pose a threat to public health, but the consumer perception of the product may be negatively affected despite the strict controls that are imposed on this product today.

Olive oil authenticity problems are associated with product labelling. Thus, the term "vegetable oil" can be correctly used for any edible oil of vegetable origin, whereas the term "olive oil" must be used for containers with oils originating exclusively from olives. In order to protect olive oils from cheaper edible oils, the current existing regulations include the definitions of their designations (extra virgin, virgin, lampante, etc.) from a conceptual perspective about which there is a general agreement. These regulations also include a definition of the designations of olive oil from a chemical viewpoint through a list of maximum or minimum values of relevant parameters on authenticity and purity. In this case, there are some disagreements among current regulations, standards and trade standards. Some of them also include the protocols of the methods to be implemented for determining the authenticity of any kind of container labelled with the term 'olive oil', whichever its designation.

From the viewpoint of analytical protocols, however, there are various standard methods for determining each one of the great number of series of chemical compounds (e.g. FAMEs, TAGs, DAGs, sterols, alcohols, waxes, ethyl esters, etc.) (León-Camacho et al., 2013) identified in olive oil designations (i.e. virgin olive oil - VOO -, olive oil - OO -, refined olive oil - ROO) and their subcategories (e.g. extra virgin olive oil -EVOO -, ordinary virgin olive oil - OVOO -, lampante virgin olive oil - LVOO) (Barjol, 2013). Standard methods compete among themselves to be the most efficient and rapid, with the highest reliability and reproducibility, and the easiest implementation inside the context of Green Chemistry that demands minimizing the use of organic solvents. This competition is now extended to methods based on nontargeted techniques that even though they have many advantages still cannot compete with chromatographic techniques in selectivity, and simplicity of interpretation of results.

Another aspect is the definition of authenticity of olive oil categories from values of their chemical components. Although the standards of the International Olive Council (IOC) are applied in a great majority of olive oil producer and importer countries and the corresponding chemical procedures are widely implemented all over the world, there are substantial differences among standards of different national and international associations as pointed out below. In some cases, these differences are a consequence of cultivating autochthonous Mediterranean varieties in nonMediterranean countries where climate is so different as to modify the concentration ranges of some chemical compounds (i.e. some fatty acids and phytosterols). The abnormal values of those compounds - associated to particular locations and/or cultivars - point out the importance of defining the correct thresholds for authentication; this fact has produced the need for updating the limits in particular situations.

This paper describes the trade standards for olive oil categories of the seven international bodies involved in this foodstuff although all of them are based on the International Olive Council (IOC) trade standard, in greater or lesser proportion. In fact, the paper begins with a description of the methodologies/methods suggested for determining the different parameters (i.e. individual or series of chemical compounds) of usefulness for olive oil authenticity, which are mostly based on those ones independently supported by five institutions (IOC, ISO, AOCS, IUPAC and Codex Alimentarius). The basic characteristics of the most commonly used method for each analysis - almost always the one proposed by IOC - are pointed out, together with comments on analytical methods, useful tips and possible improvements followed by a description of alternatives from non-targeted techniques when described in the scientific bibliography. The analytical quality parameters of the mentioned methods are also described although this information is exclusively given by IOC. The analysis of each method ends with the approved values (maximum/minimum) for each one of the parameters quantified with the method according to the regulations of the seven international bodies (International Olive Council, Codex Alimentarius, and the corresponding regulatory bodies of European Union, United States of America, State of California, Australia, and South Africa). 


\section{TRADE STANDARDS INSIDE AND OUTSIDE EUROPEAN UNION (EU)}

\subsection{International institutions involved in olive oil regulations and trade standards}

The named seven international regulatory bodies, which are involved in producing trade standards for olive oil, share most of the physical-chemical parameters currently accepted for determining the purity, quality and authenticity of any oil included in a container labelled with some of the olive oil designations accepted by trade standards. A brief description of the characteristics of each one of the seven international bodies is given next for those readers less familiar with some of them.

- International Olive Council (IOC) (http://www. internationaloliveoil.org/): It can be considered the reference regulatory body because it is the only intergovernmental organization in the world (set up in 1959 under the auspices of the United Nations) that brings together most of olive oil producing and consuming stakeholders. The latest trade standard was published in July 2016 (COI/T.15/NC No 3/Rev. 11 - Trade standard applying to olive oils and olive-pomace oils). In addition, each parameter is associated with a standard method which is regularly updated.

- Codex Alimentarius (http://www.fao.org/fao-whocodexalimentarius/codex-home/es/): The Codex Alimentarius or "Food Code" was established by the FAO and the World Health Organization in 1963 to develop harmonized international food standards, and it includes specific chemical limits for olive oil designations. The last regulation is Codex Standard for Olive Oils and Olive Pomace Oils (CODEX STAN 33-1981). No own analytical methods are associated.

- European Union (http://ec.europa.eu/agriculture/olive-oil_en): The European Union regulation includes a complete norm on olive oil including limits and associated methods. Similarly to the IOC, the European Union also has an expert group that discusses the methods and limits to be adapted to new situations (Directorate-General for Agriculture and Rural Development: Sub-group Olive Oil). The last EU norm was published in September 2016 (Commission Delegated Regulation (EU) 2016/2095 of 26 September 2016 amending Regulation (EEC) No 2568/91).

- United States of America (USA) (https://www. ams.usda.gov/grades-standards/olive-oil-and-olive-pomace-oil-grades-and-standards): In 2010, The United States Department of Agriculture published its own regulation on olive oil entitled "United States Standards for Grades of Olive
Oil and Olive-Pomace Oil". In addition to establishing limits, it includes references to standard methods of other regulatory bodies.

- California(USA)(https://www.cdfa.ca.gov): The State of California (Californian Department of Food and Agriculture, CDFA) also published its own regulation in 2014: Grade and Labelling Standards for Olive Oil, Refined-Olive Oil and Olive-Pomace Oil. This regulation includes both limits of physical-chemical parameters and references to standard methods of other regulatory bodies. Some amendments were included in and September 2016.

- Australia (http://www.aph.gov.au/): The norm "Olive oils and olive-pomace oils" was published by the Australian Standards (AS 52642011). This norm includes limits, references to analytical methods of other regulatory bodies, and some instruction in terms of contaminants, food additives, etc.

- South African National Standard (SANS) (https://www.sabs.co.za/): The South African Bureau of Standards (SABS) provides standards and conformity assessment for a wide variety of materials. The last norm concerning olive oil is SANS 1377 (2015).

\subsection{Standard methods for determinations of parameters involved in authenticity, purity and quality}

The differences in information, among the actual regulations and trade standards supported by the named international regulatory bodies, concern not only olive oil designations (i.e., ordinary virgin olive oil is exclusively regulated by IOC trade standard) and the values of the parameters involved in purity and authenticity - as is described below - but also applies to the methods suggested for determining those parameters. Table 1 displays the analytical methods suggested for determining the physicalchemical parameters described in the first column. The information in the table is useful as a crosscomparison methodology, as it allows easy checking of the different analytical methods proposed by the international bodies for the determination of each series of chemical compounds and physical measurements. Prior to the individual analysis of each determination described in Table 1 , there are three main general conclusions that need basic explanations:

- The analytical methods suggested by the cited institutions to determine the demanded saponifiable and unsaponifiable chemical series (e.g., FAMES, TAG, sterols etc.) are those supported by IOC, ISO and AOCS although the methods proposed by IOC are much more focused on 


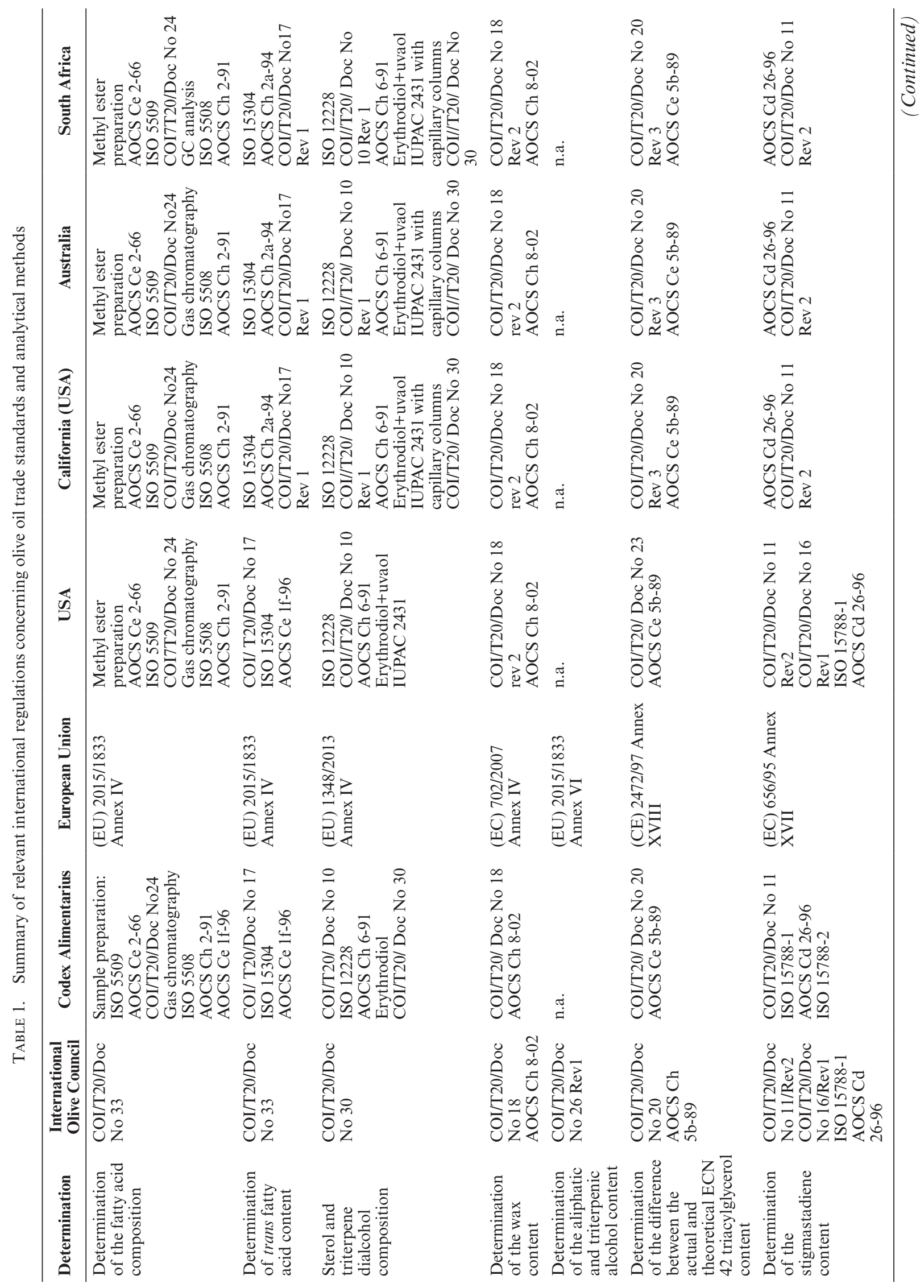


A study of the differences between trade standards inside and outside Europe $\bullet$

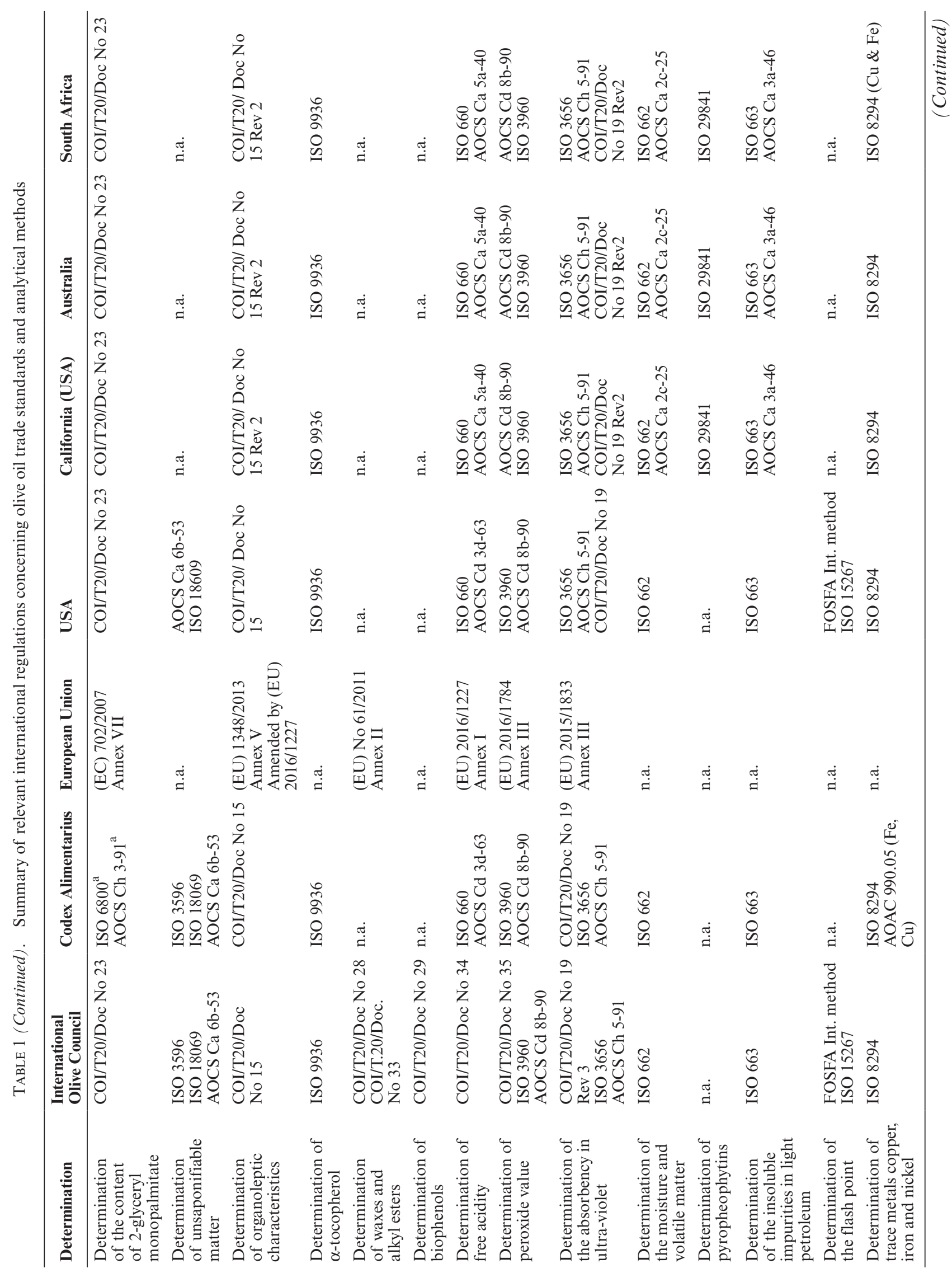




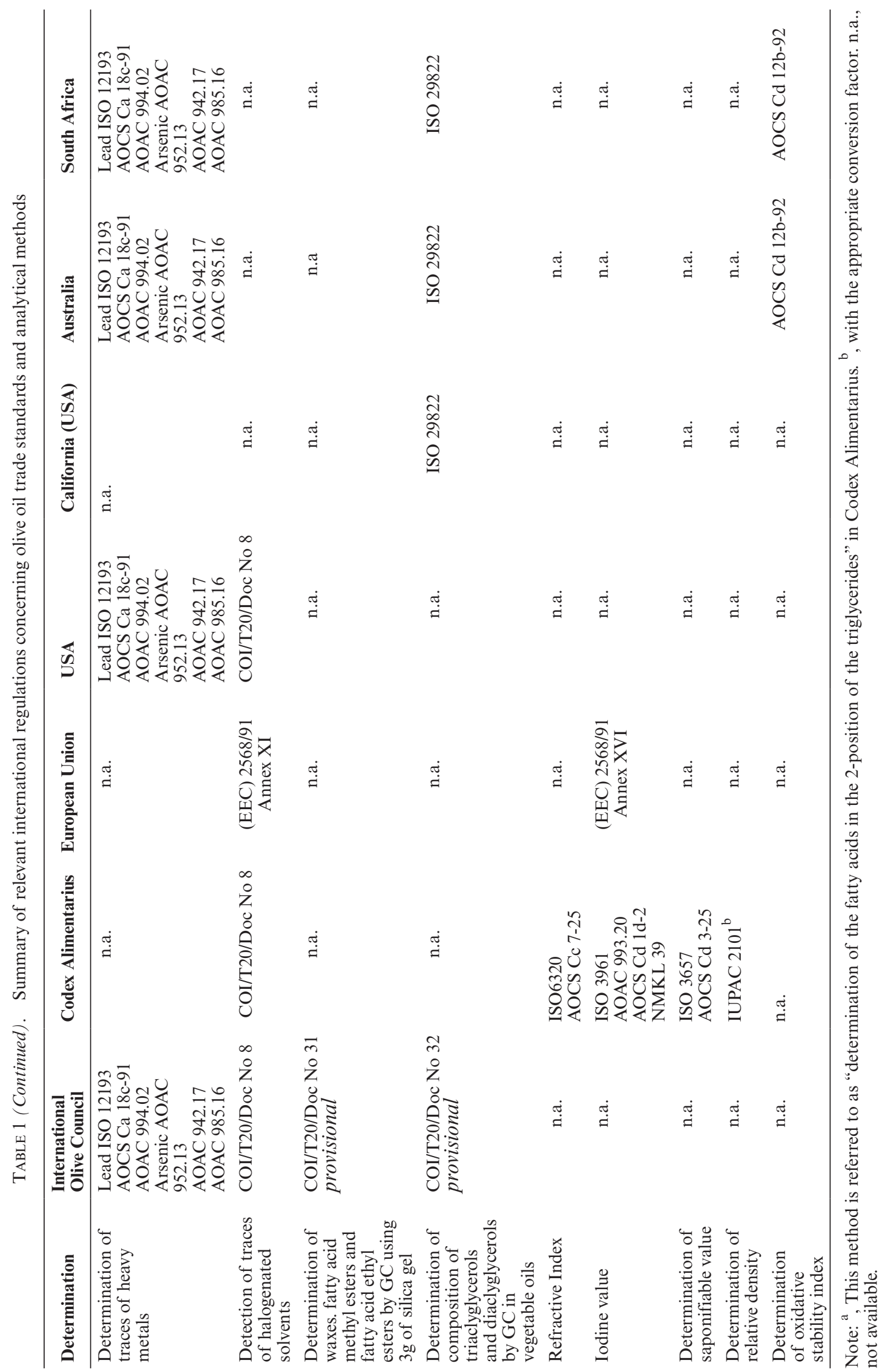


olive oil and show more advantages when compared with others.

- Other chemical compounds (i.e. FAEE, waxes, bio-phenols) are supported by the IOC but not for the other institutions and vice versa (i.e. PPP)

- The analytical methods for determining physical parameters are mostly based on ISO analytical methods, and they are supported by all the institutions.

\subsection{In-depth analysis of standard methods and values of parameters linked to olive oil purity and quality}

This information, however, does not describe the most noticeable characteristics of the IOC analytical methods suggested for determining the most remarkable chemical parameters affecting the determination of olive oil purity and hence the detection of adulterated olive oil samples.

The description of each IOC analytical method is followed with a series of comments, useful tips and amendments to this current standard method, and there is a table showing the range or maximum or minimum values of each one of the chemical compounds determined with the analytical method in order to decide whether an olive oil is genuine according to the current international regulations. The values of repeatability and reproducibility of IOC methods are then displayed although more information on analytical quality parameters is provided on the IOC website. Each section ends with alternatives to standard methods (Table 1) from non-targeted techniques when they are reliable.

\subsubsection{Determination of fatty acid composition}

The procedure proposed by the IOC for determining the content of FAME from $\mathrm{C} 12$ to $\mathrm{C} 24$, including saturated, cis- and trans-monounsaturated, and cis- and trans-polyunsaturated fatty acid by GC analysis of methyl esters is COI/T.20/Doc. No 33 (February 2015).

This method, which has been revised several times, helps to determine olive oil purity and authenticity by transesterification with a potassium hydroxide solution in methanol at room temperature for oils with acidity $\leq 2.0$ while olive oils with higher acidity and crude olive pomace oils require purification with silica-gel SPE prior to transesterification. In the last revisions, the figures have been set with two decimal points and the limits of heptadecanoic, heptadecenoic and eicosenoic fatty acid methyl esters have been changed, and consequently there are some differences with the other norms.

Although being an IOC standard method, it is not exempted of improvements, comments and useful tips. Some of those are:
- The high diversity of available chromatographic columns can produce differences in the performance of the method. In general terms, the columns characterized by highest polarity are indicated for a better separation of polyunsaturated fatty acids, while the lower polarity is better for saturated and monoenoic compounds with the same chain length. In order to have a good separation of trans fatty acids it is advisable to use columns of $50 \mathrm{~m}$ or longer (e.g. a column of $50 \mathrm{~m} \times 0.20-0.32 \mathrm{~mm}$ i.d. $0.1 \times 0.2$ $\mu \mathrm{m}$ film thickness with a cross-linked stationary phase of cyanopropylsiloxane).

- In aged columns, some deviations from the normal retention times can be observed as a consequence of polymerization of the stationary phase.

- Hydrogen results in a better peak resolution than helium.

Table 2 displays the differences between the limit values for each fatty acid established in the trade standards (also regulations or norms) of each international regulatory body. IOC and EU provide the same values, and hence they are shown in the same column. Only when there are differences between the other regulations and IOC the values are shown in the table. The last two columns on the right side of the table show the range of variation of repeatability - as $\mathrm{RSD}_{\mathrm{r}}$ - and reproducibility - as $\mathrm{RSD}_{\mathrm{R}}-$ for the method supported by IOC. Values are given by IOC according to internal blind trials. Some differences between standards are mentioned below:

- IOC and EU values are given with two decimal places while most of the other norms express the figures with one decimal. This may cause some disagreements among norms.

- Codex Alimentarius shows slightly different figures for myristic, heptadecanoic, heptadecenoic, linolenic and gadoleic acids. It is important to point out that IOC and Codex are undergoing a process of harmonization of values. It is also important to note that some climate changes are causing some changes in fatty acid composition in some cultivars, and some regulations have needed to be updated to favor the international market.

- USDA standards (USA) contain the same disagreement as Codex Alimentarius.

- In the Californian standard, the disagreements are focused on myristic and heptadecanoic acids, and on the fact that no values are indicated for palmitic, palmitoleic, heptadecenoic, oleic, linoleic, or gadoleic acids.

- The Australian Standard has the same disagreement as the Codex Alimentarius, and in addition has different values for palmitic and oleic acid.

- The South African standard shows the same values as the Australian standard. 
TABLE 2. Limit values of the fatty acids ( $\% \mathrm{~m} / \mathrm{m}$ methyl esters) for all olive oil categories according to IOC, and differences found in other international regulations with respect to IOC values. Blank cells mean that no difference is observed compared with IOC standard. Values of analytical parameters (repeatability and reproducibility) extracted from the IOC methods are also given

\begin{tabular}{lcccccccc}
\hline Parameter & IOC/EU & $\begin{array}{c}\text { Codex } \\
\text { Alimentarius }\end{array}$ & USA & $\begin{array}{c}\text { California } \\
\text { (USA) }\end{array}$ & Australia & $\begin{array}{c}\text { South } \\
\text { Africa }\end{array}$ & $\begin{array}{c}\mathbf{R}_{\mathbf{R}} \\
(\%)\end{array}$ & $\begin{array}{c}\mathbf{R}_{\mathbf{r}} \\
(\%)\end{array}$ \\
\hline Myristic acid (C14:0) & $\leq 0.03$ & $\leq 0.05$ & $\leq 0.05$ & $\leq 0.05$ & $\leq 0.05$ & $\leq 0.05$ & $11-38$ & $32-52$ \\
Palmitic acid (C16:0) & $7.50-20.00$ & & & n.i. & $7.0-20.0$ & $7.0-20.0$ & $0.53-1.5$ & $1.5-4.7$ \\
Palmitoleic acid (C16:1) & $0.30-3.50$ & & & n.i. & & & $1.3-3.6$ & $4.1-7.2$ \\
Heptadecanoic acid (C17:0) & $\leq 0.40$ & $\leq 0.3$ & $\leq 0.3$ & $\leq 0.3$ & $\leq 0.3$ & $\leq 0.3$ & n.i. & n.i. \\
Heptadecenoic acid (C17:1) & $\leq 0.60$ & $\leq 0.3$ & $\leq 0.3$ & n.i. & $\leq 0.4$ & $\leq 0.4$ & n.i. & n.i. \\
Stearic acid (C18:0) & $0.50-5.00$ & & & & & & $0.49-1.2$ & $2.1-3.8$ \\
Oleic acid (C18:1) & $55.00-83.00$ & & & n.i. & $53.0-85.0$ & $53.0-85.0$ & $0.11-0.21$ & $0.60-0.85$ \\
Linoleic acid (C18:2) & $2.50-21.00$ & $3.5-21.0$ & $3.5-21.0$ & n.i. & $2.5-22.0$ & $2.5-22.0$ & $0.2-0.70$ & $1.7-2.4$ \\
Linolenic acid (C18:3) & $\leq 1.00$ & n.i. & $\leq 1.5$ & n.i. & $\leq 1.5$ & $\leq 1.5$ & $1.2-2.6$ & $3.8-5.4$ \\
Arachidic acid (C20:0) & $\leq 0.60$ & & & & & & $3.0-4.4$ & $7.0-9.8$ \\
Gadoleic acid (eicosenoic) (C20:1) & $\leq 0.50$ & $\leq 0.4$ & $\leq 0.4$ & n.i. & & & $3.0-8.9$ & $6.2-10.0$ \\
Behenic acid (C22:0) & $\leq 0.20$ & & & & & & $6.9-14.0$ & $8.3-17.0$ \\
Lignoceric acid (C24:0) & $\leq 0.20$ & & & & & & $8.9-24.0$ & $19.0-49.0$ \\
\hline
\end{tabular}

Note: n.i., not indicated (there is no value specified for this parameter/category). RSDr (\%), relative standard deviation for repeatability, $\mathrm{RSD}_{\mathrm{R}}(\%)$, relative standard deviation for reproducibility. A range is shown since the value can vary between different categories of olive and olive-pomace oils.

All the international institutions (i.e. IOC, ISO, AOCS) involved in setting up analytical procedures for determining the fatty acid composition have designed methods based on chromatography but there are alternatives from non-targeted techniques although they cannot identify individual fatty acids as the current standard requires. The use of mathematical equations using signal intensities as variables can provide useful information on saturated fatty acids (SFAs), the monounsaturated oleic acid (MUFA), and the polyunsaturated linoleic and linolenic acids (PUFAs). One of these alternatives is ${ }^{1} \mathrm{H}-\mathrm{NMR}$ spectroscopy. It shows a good performance for FA quantification although there is some deviation from the GC results in some individual fatty acids (e.g. saturated compounds), partly due to the sensitivity in the integration step. More detailed information can be found in Dais (2013).

\subsubsection{Determination of trans fatty acid content}

The method described above - COI/T.20/Doc. No 33 (February 2015) - is also used for quantifying the trans isomers of fatty acids, which allows detecting the presence of heated or refined oils. According to the differences between the IOC standard and other regulations, only the standard of the Codex Alimentarius includes a difference consisting in no specification for the categories of lampante oil and crude pomace oil (Table 3). The measures of precision (repeatability and reproducibility) for the method proposed by IOC reach high values because trans percentages oscillate from high values in crude olive pomace oil to negligible in EVOO. Suggestions have been made to improve the results such as using long columns (e.g. $88 \%$ cyanopropyl aryl siloxane $100 \mathrm{~m} \times 0.2 \mathrm{~mm}$ i.d. $\times$ $0.2 \mu \mathrm{m}$ film thickness), which are more appropriate for separating trans fatty acids, although some analysts say that a column of $50 \mathrm{~m}$ is sufficient for separating cis and trans fatty acids with a good resolution.

The alternative to the standard method based on chromatography is the use of spectroscopy (FTIR and FT-Raman) as cis and trans isomers have clear and reliable bands; i.e. Raman bands near 1656 and $1670 \mathrm{~cm}^{-1}$. The use of vibrational spectroscopy unexplainably fell into disuse some years ago despite the fact that it is more rapid, cheaper and easier to use than chromatography.

\subsubsection{Determination of sterols and triterpene dialcohols}

The IOC sets up an analytical procedure - COI/ T20/Doc No 30 (November 2013) - for determining the content of individual and total phytosterols or 4-desmethylesterols and erythrodiol and uvaol. This method is used to detect the presence of vegetable edible oils in olive oils (by means of sterol contents) and to detect the presence of pomace oils in olive oils (by means of triterpene dialcohols). The wellknown procedure consists of the steps of saponification, separation of the unsaponifiable matter with ethyl ether, separation of sterol fraction by thin layer chromatography on silica gel, transformation of sterols into trimethyl-silyl ethers and analysis by gas chromatography. 
TABLE 3. Limit values of the trans fatty acids ( $\% \mathrm{~m} / \mathrm{m}$ methyl esters) for all olive oil categories according to IOC, and differences found in other international regulations with respect to IOC values. Blank cells mean that no difference is observed compared with IOC standard. Values of analytical parameters (repeatability and reproducibility) extracted from the IOC methods are also given

\begin{tabular}{|c|c|c|c|c|c|c|c|c|}
\hline Parameter & IOC/EU & $\begin{array}{c}\text { Codex } \\
\text { Alimentarius } \\
\end{array}$ & USA & $\begin{array}{c}\text { California } \\
\text { (USA) }\end{array}$ & Australia & $\begin{array}{l}\text { South } \\
\text { Africa }\end{array}$ & $\mathrm{RSD}_{\mathrm{r}}(\%)$ & $\operatorname{RSD}_{\mathrm{R}}(\%)$ \\
\hline C18:1t: Edible virgin olive oil & $\leq 0.05$ & & & & & & & \\
\hline C18:1t : LVOO & $\leq 0.10$ & n.i. & & & & & & \\
\hline $\mathrm{C} 18: 1 \mathrm{t}: \mathrm{ROO}, \mathrm{OO}+$ & $\leq 0.20$ & & & & & & $13.0-41.0$ & $48.0-100.0$ \\
\hline $\mathrm{C} 18: 1 \mathrm{t}: \mathrm{ROPO}, \mathrm{OPO}+$ & $\leq 0.40$ & & & & & & & \\
\hline C18:1t: COPO & $\leq 0.20$ & n.i. & & & & & & \\
\hline $\mathrm{C} 18: 2 \mathrm{t}+\mathrm{C} 18: 3 \mathrm{t}$ : Edible virgin olive oil & $\leq 0.05$ & & & & & & & \\
\hline $\mathrm{C} 18: 2 \mathrm{t}+\mathrm{C} 18: 3 \mathrm{t}: \mathrm{LVOO}$ & $\leq 0.10$ & n.i. & & & & & & \\
\hline $\mathrm{C} 18: 2 \mathrm{t}+\mathrm{C} 18: 3 \mathrm{t}: \mathrm{ROO}, \mathrm{OO}+$ & $\leq 0.30$ & & & & & & $24.0-115.0$ & $81.0-130.0$ \\
\hline $\mathrm{C} 18: 2 \mathrm{t}+\mathrm{C} 18: 3 \mathrm{t}: \mathrm{ROPO}, \mathrm{OPO}+$ & $\leq 0.35$ & & & & & & & \\
\hline $\mathrm{C} 18: 2 \mathrm{t}+\mathrm{C} 18: 3 \mathrm{t}: \mathrm{COPO}$ & $\leq 0.10$ & n.i. & & & & & & \\
\hline
\end{tabular}

Note: n.i., not indicated (there is no value specified for this parameter/category). Edible virgin olive, includes EVOO, VOO OVOO; EVOO, extra-virgin olive oil; VOO, virgin olive oil; OVOO, ordinary virgin olive oil; LVOO, lampante virgin olive oil; ROO, refined olive oil; $\mathrm{OO}+$, olive oil (mix of virgin and refined olive oils); COPO, crude olive-pomace oil; ROPO, refined olive-pomace oil; OPO+, olive-pomace oil (mix of refined pomace oil and virgin olive oil). RSDr (\%), relative standard deviation for repeatability, $\mathrm{RSD}_{\mathrm{R}}(\%)$, relative standard deviation for reproducibility. A range is shown since the value can vary between different categories of olive and olivepomace oils. Precision values for C18:2t are 24.0-70.0 for repeatability and 71.0-105.0 for reproducibility.

Although the method has been revised several times there are aspects that are in need of improvement with useful tips as well as comments for future changes in the data presentation. They are:

- Sterols are much better separated by TLC on silica gel with hexane/diethyl ether $(65: 35 \mathrm{v} / \mathrm{v})$ if two developments are carried out.

- Improvements have also been made by substituting TLC by HPLC separation. The new method includes the following steps: (i) separation of the fraction of sterols by HPLC with a silica gel column, (ii) collection of the fraction, (iii) elimination of the solvent, (iv) further derivation, and (v) injection onto GC. This approach is not included in any regulation yet though similar methods are being explored at the moment since some industry labs already use HPLC for sterol analysis with success.

Special mention can be made about the change suggested in the data presentation. Currently, individual sterols are given in percentages of the total area of sterols while the suggestion is to give the data of individual sterols in absolute concentration because of the possibility of some illegal processes for removing sterols without forming fatty acid trans-isomers. This approach would involve updating the regulations with a new method resulting from further studies.

Table 4 shows the limit values for individual and total sterols and the sum of erythrodiol and uvaol according to the international regulatory bodies. IOC and EU provide the same values, and hence they are shown in the same column. Table 4 also shows the main difference in the limits for campesterol and stigmasterol. There is a biochemical explanation, and empirical results confirm that the concentrations of those two compounds are affected by latitude and altitude of olive tree orchards (Aparicio et al., 1994). The scientific bases have added fuel to the debate about how olive oils from new producing regions (mostly in the Southern Hemisphere) can be classified as genuine without compromising the control of the adulteration that a change in limits of these sterols would mean for the rest of world production. Thus, IOC has included decision trees for olive oils with percentages of campesterol between 4.0 and 4.5 with the objective of classifying those oils as genuine oils, because they are, but without comprising the fight against olive oil fraud. However, some regulations, such as Australian and South African standards, have even established a limit higher than 4.5 while they do not include any limit for total sterols and erythrodiol plus uvaol. In the attempt to develop a single regulation, a harmonization program between IOC and Codex Alimentarius is currently in progress.

An alternative to chromatographic methods comes from ${ }^{1} \mathrm{H}-\mathrm{NMR}$ and ${ }^{31} \mathrm{P}-\mathrm{NMR}$ (Dais, 2013) although individual sterols cannot be quantified individually in such an exhaustive manner as GC does. Total free and esterified sterols can be determined by NMR but it requires strong magnetic fields ( $\geq 500 \mathrm{MHz}$ ).

The application of vibrational spectroscopy to the determination of sterols, not individually but their total, faces the problem of the barrier effect that is exerted by saponifiable matter in the spectra acquisition (Baeten et al., 2001). One of the 
TABLE 4. Limit values of sterols and triterpenic alcohols (values given in percentage except for total sterol, which is given in $\mathrm{mg} / \mathrm{kg}$ ) for all olive oil categories according to IOC, and differences found in other international regulations with respect to IOC values. Blank cells mean that no difference is observed compared with IOC standard. Values of analytical parameters (repeatability and reproducibility) extracted from the IOC methods are also given

\begin{tabular}{|c|c|c|c|c|c|c|c|c|}
\hline Parameter & IOC/EU & $\begin{array}{c}\text { Codex } \\
\text { Alimentarius }\end{array}$ & USA & $\begin{array}{l}\text { California } \\
\text { (USA) }\end{array}$ & Australia & $\begin{array}{l}\text { South } \\
\text { Africa }\end{array}$ & $\begin{array}{c}\operatorname{RSD}_{\mathbf{r}} \\
(\%)\end{array}$ & $\begin{array}{c}\mathbf{R S D}_{\mathrm{R}} \\
(\%)\end{array}$ \\
\hline Cholesterol & $\leq 0.5$ & & n.i. & & & & $7.2-18.8$ & $17.8-31.9$ \\
\hline Brassicasterol & $\leq 0.1^{\mathrm{a}}$ & & & & & & $2.7-32.7$ & $3.6-115.2$ \\
\hline Campesterol & $\leq 4.0^{\mathrm{b}}$ & & $\leq 4.5^{\mathrm{d}}$ & n.i. & $\leq 4.8$ & $\leq 4.8$ & $0.9-1.4$ & $2.4-2.9$ \\
\hline Stigmasterol & $\begin{array}{l}<\text { campesterol } \\
\text { in edible oils }\end{array}$ & & & $\leq 1.9$ & $\leq 1.9$ & $\leq 1.9$ & $1.5-11.1$ & $2.9-15.6$ \\
\hline$\Delta^{7}$-stigmastenol & $\leq 0.5^{\mathrm{b}}$ & & & n.i. & & & $2.6-9.5$ & $4.9-25.3$ \\
\hline Apparent $\beta$-sitosterol $^{\mathrm{c}}$ & $\geq 93.0$ & & & n.i. & $\geq 92.5$ & $\geq 92.5$ & $0.10-0.26$ & $0.36-1.75$ \\
\hline $\begin{array}{l}\text { Total sterol content in EVOO, VOO, } \\
\text { OVOO, ROO, OO+ }\end{array}$ & $\geq 1000$ & & & & & & & \\
\hline Total sterol content in COPO & $\geq 2500$ & n.i. & & & & & $1.5-3.3$ & $5.8-8.4$ \\
\hline Total sterol content in ROPO & $\geq 1800$ & & & & & & & \\
\hline Total sterol content in $\mathrm{OPO}+$ & $\geq 1600$ & & & & & & & \\
\hline $\begin{array}{l}\text { Erythrodiol and uvaol content (\% total } \\
\text { sterols) in EVOO, VOO, OVOO, ROO, OO+ }\end{array}$ & $\leq 4.5$ & & & n.i. & & & $0-153$ & $16-32 ?$ \\
\hline $\begin{array}{l}\text { Erythrodiol and uvaol content ( } \% \text { total } \\
\text { sterols) in COPO, ROPO, OPO+ }\end{array}$ & $>4.5$ & n.i. & & n.i. & & & $.0-15.0$ & $4.0-32.2$ \\
\hline
\end{tabular}

Note: ${ }^{\text {a }}$, Limit raised to $<0.2$ for olive pomace oils; ${ }^{b}$, subjected to decision trees; ${ }^{\mathrm{c}}$, sum of $\beta$-sitosterol $+\Delta^{5}$-avenasterol $+\Delta^{5,23}$. stigmastadienol + clerosterol + sitostanol $+\Delta^{5,24}$-stigmastadienol); ${ }^{d}$, campesterol values between 4.0 and 4.5 would be subjected to further testing; n.i., not indicated (there is no value specified for this parameter/category). EVOO, extra-virgin olive oil; VOO, virgin olive oil; OVOO, ordinary virgin olive oil; LVOO, lampante virgin olive oil; ROO, refined olive oil; OO+, olive oil (mix of virgin and refined olive oils); COPO, crude olive-pomace oil; ROPO, refined olive-pomace oil; OPO +, olive-pomace oil (mix of refined pomace oil and virgin olive oil). RSDr (\%), relative standard deviation for repeatability, $\mathrm{RSD}_{\mathrm{R}}(\%)$, relative standard deviation for reproducibility. A range is shown since the value can vary between different categories of olive and olive-pomace oils.

problems in vibrational spectroscopy is caused by the interferences of the saponifiable matter (fatty acids and TAGs) when determining unsaponifiable compounds (i.e. sterols). For this reason, investigation to avoid this interference should be prioritized because it still means the last hurdle to apply vibrational spectroscopy as an alternative to chromatography with the advantages of speed and good precision.

\subsubsection{Determination of the wax content}

The determination of this series of compounds, which can be made by applying two different IOC methods, is carried out when the objective is to distinguish olive oil from olive pomace oil. In both methods, the separation of waxes is carried out according to their number of carbon atoms. The IOC method COI/T.20/Doc. No 18/Rev. 2 (December 2003), which describes the determination of the even numbered carbon atoms of individual waxes from C40 to $\mathrm{C} 46$, is based on the separation of wax fraction by column chromatography on hydrated silica gel, and then the obtained fraction is analyzed by gas chromatography. An alternative is the IOC method COI/T.20/Doc. No 28/Rev. 1 (2010) that allows determining waxes together with fatty acid methyl esters and fatty acid ethyl esters; the last compounds can indicate the existence of a fermentative process prior to and during the elaboration of virgin olive oil.

The results of the standard method based on document No 18 can improve if the analysts use SPE cartridges instead of silica gel columns for sample purification. Cartridges require smaller amounts of sample and a reduced volume of elution solvent.

Table 5 shows differences in the trade standards among the international regulatory bodies and IOC. The main difference is that C40 is not included in the computation of the sum of wax concentration in the IOC regulation since a recent modification of the norm. On the other hand, the IOC standard includes a different value for ordinary and lampante categories, while the first category (ordinary) is not defined by the rest of the regulations. The standard of Codex Alimentarius does not include this separation of categories and establishes a maximum value of $250 \mathrm{mg} / \mathrm{kg}$ for all the virgin olive oil categories. This standard does not include any instruction about how to calculate this sum, although it referrers to the IOC and AOCS methods (COI/T.20/Doc. no. 18 or AOCS Ch 8-02).

No alternative methods from non-targeted techniques with enough scientific support as to be reliable have been identified in the bibliography. It seems the 
TABLE 5. Limit values of wax composition $(\mathrm{mg} / \mathrm{kg})$ for all olive oil categories according to IOC, and differences found in other international regulations with respect to IOC values. Blank cells mean that no difference is observed compared with IOC standard. Values of analytical parameters (repeatability and reproducibility) extracted from the IOC methods are also given

\begin{tabular}{|c|c|c|c|c|c|c|c|c|}
\hline Parameter & $\begin{array}{c}\text { IOCI } \\
\text { EU }\end{array}$ & $\begin{array}{c}\text { Codex } \\
\text { Alimentarius } \\
\end{array}$ & USA & $\begin{array}{l}\text { California } \\
\text { (USA) }\end{array}$ & Australia & $\begin{array}{l}\text { South } \\
\text { Africa }\end{array}$ & $\operatorname{RSD}_{\mathrm{r}}(\%)$ & $\operatorname{RSD}_{\mathrm{R}}(\%)$ \\
\hline $\mathrm{C} 42+\mathrm{C} 44+\mathrm{C} 46: \mathrm{EVOO}, \mathrm{VOO}$ & $\leq 150$ & $\leq 250^{\mathrm{b}}$ & $\leq 250^{\mathrm{c}}$ & $\leq 250^{\mathrm{c}}$ & $\leq 250^{\mathrm{c}}$ & $\leq 250^{\mathrm{c}}$ & & \\
\hline $\mathrm{C} 40+\mathrm{C} 42+\mathrm{C} 44+\mathrm{C} 46: \mathrm{OVOO}$ & $\leq 250^{\mathrm{a}}$ & $\leq 250^{\mathrm{b}}$ & n.i. & n.i. & n.i. & n.i. & & \\
\hline $\mathrm{C} 40+\mathrm{C} 42+\mathrm{C} 44+\mathrm{C} 46: \mathrm{LVOO}$ & $\leq 300$ & n.i. & & & & & $1.54-3.64$ & $4.58-14.18$ \\
\hline $\mathrm{C} 40+\mathrm{C} 42+\mathrm{C} 44+\mathrm{C} 46: \mathrm{ROO}, \mathrm{OO}+$ & $\leq 350$ & & & & & & & \\
\hline $\begin{array}{l}\mathrm{C} 40+\mathrm{C} 42+\mathrm{C} 44+\mathrm{C} 46: \mathrm{COPO}, \mathrm{ROPO} \\
\mathrm{OPO}+\end{array}$ & $>350$ & (d) & & & & & & \\
\hline
\end{tabular}

Note: ${ }^{\text {a }}$, the ordinary category is not defined in the EU regulation; ${ }^{\mathrm{b}}$. It does not specify the waxes included in the computation of the sum; ${ }^{c}, \mathrm{C} 40$ is also included in the sum of waxes; ${ }^{\mathrm{d}}$, crude pomace oil category is not defined in the Codex Alimentarius standard; n.i., not indicated (there is no value specified for this parameter/category). RSDr (\%), relative standard deviation for repeatability, RSDR $(\%)$, relative standard deviation for reproducibility. A range is shown since the value can vary between different categories of olive and olive-pomace oils. EVOO, extra-virgin olive oil; VOO, virgin olive oil; OVOO, ordinary virgin olive oil; LVOO, lampante virgin olive oil; ROO, refined olive oil; OO+, olive oil (mix of virgin and refined olive oils); COPO, crude olive-pomace oil; ROPO, refined olivepomace oil; $\mathrm{OPO}+$, olive-pomace oil (mix of refined pomace oil and virgin olive oil).

TABLE 6. Limit values of $\triangle \mathrm{ECN} 42$ for all olive oil categories according to IOC, and differences found in other international regulations with respect to IOC values. Blank cells mean that no difference is observed compared with IOC standard. Values of analytical parameters (repeatability and reproducibility) extracted from the IOC methods are also given

\begin{tabular}{|c|c|c|c|c|c|c|c|c|}
\hline Parameter & IOC/EU & $\begin{array}{c}\text { Codex } \\
\text { Alimentarius } \\
\end{array}$ & USA & $\begin{array}{l}\text { California } \\
\text { (USA) }\end{array}$ & Australia & $\begin{array}{l}\text { South } \\
\text { Africa }\end{array}$ & $\mathrm{RSD}_{\mathbf{r}}(\%)$ & $\mathrm{RSD}_{\mathrm{R}}(\%)$ \\
\hline 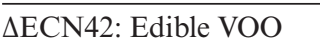 & $\leq|0.2|^{\mathrm{a}}$ & & & & & & \multirow{4}{*}{$\begin{array}{c}2.77-22.51 \\
(1.57-36.60)^{\mathrm{e}}\end{array}$} & \multirow{4}{*}{$\begin{array}{c}5.42-46.19 \\
(11.21-36.80)^{\mathrm{e}}\end{array}$} \\
\hline $\begin{array}{l}\triangle \mathrm{ECN} 42: \mathrm{LVOO}, \mathrm{ROO} \\
\mathrm{OO}+\end{array}$ & $\leq|0.3|$ & & & & & & & \\
\hline$\triangle \mathrm{ECN} 42: \mathrm{COPO}$ & $\leq|0.6|$ & (c) & & & & & & \\
\hline$\triangle \mathrm{ECN} 42: \mathrm{ROPO}, \mathrm{OPO}+$ & $\leq|0.5|$ & (d) & & & & & & \\
\hline
\end{tabular}

Note: $\triangle \mathrm{ECN} 42$, difference between the actual and theoretical contents of ECN 42 triacylglycerols; edible virgin olive oil, includes EVOO, VOO and OVOO; EVOO, extra-virgin olive oil; VOO, virgin olive oil; OVOO, ordinary virgin olive oil; LVOO, lampante virgin olive oil; ROO, refined olive oil; OO+, olive oil (mix of virgin and refined olive oils); COPO, crude olive-pomace oil; ROPO, refined pomace oil; $\mathrm{OPO}+$, pomace oil (mix of refined pomace oil and virgin olive oil), ${ }^{\text {a }}$, ordinary virgin olive oil is not a category defined in the EU regulation; ${ }^{b}$, lampante virgin olive oil is not a category defined by Codex Alimentarius; ${ }^{\mathrm{c}}$, crude olive pomace oil is not a category defined by Codex Alimentarius; ${ }^{\mathrm{d}}$, olive pomace oil is not a category defined by Codex Alimentarius; ${ }^{\mathrm{e}}$, determination of analytical quality parameter using propionitrile as solvent in the method; n.i., not indicated (there is no value specified for this parameter/category). RSDr (\%), relative standard deviation for repeatability, $\mathrm{RSD}_{\mathrm{R}}(\%)$, relative standard deviation for reproducibility. A range is shown since the value can vary between different categories of olive and olive-pomace oils.

scientific community is not interested in determining waxes in olive oil by NMR spectroscopy, despite the fact that ${ }^{13} \mathrm{C}$-NMR has been successfully applied to determine the structures of natural derivatives of long-chain fatty acids and, in particular, waxes and glycerides.

\subsubsection{Determination of the difference in content between the actual and theoretical ECN 42 triacylglycerols.}

The method coded COI/T.20/Doc. No 20 /Rev. 3 (2010) describes a procedure for determining the content of triacylglycerols (TAGs) with an equivalent carbon number equal to 42 (ECN 42). This method is used to detect the presence of small amounts of seed oils in olive oils. The procedure consists of four steps: (i) determination of fatty acid composition by capillary gas chromatography; (ii) calculation of theoretical composition of TAGs with equivalent carbon number equal to 42 (ECN 42) (there is a computer program to carry out this calculation); (iii) determination of TAGs with ECN 42 by HPLC; and (iv) determination of the absolute difference between both values of TAGs with ECN 42. A difference larger than the established values indicates the presence of seed oils.

Table 6 shows the limits of $\triangle \mathrm{ECN} 42$ for each one of the olive oil categories, according to IOC, in absolute values. No differences were found in the values, except for the absence of specific values for lampante virgin olive oil (LVOO) and crude olive-pomace oil (COPO) in the case of the Codex Alimentarius standard. This kind of analysis, however, is not exempt of problems that have been tried to minimize with useful tips. Thus, in the analysis of fatty acids for 
TABLE 7. Limit values of stigmastadiene contents $(\mathrm{mg} / \mathrm{kg})$ for all olive oil categories according to IOC, and differences found in other international regulations with respect to IOC values. Blank cells mean that no difference is observed compared with IOC standard. Values of analytical parameters (repeatability and reproducibility) extracted from the IOC methods are also given

\begin{tabular}{|c|c|c|c|c|c|c|c|c|}
\hline Parameter & IOC/EU & $\begin{array}{c}\text { Codex } \\
\text { Alimentarius }\end{array}$ & USA & $\begin{array}{l}\text { California } \\
\text { (USA) }\end{array}$ & Australia & South Africa & $\operatorname{RSD}_{\mathrm{r}}(\%)$ & $\mathrm{RSD}_{\mathrm{R}}(\%)$ \\
\hline $\begin{array}{l}\text { Stigmastadiene content in EVOO } \\
\text { and VOO }\end{array}$ & $\leq 0.05$ & $\leq 0.15$ & $\leq 0.15$ & $\leq 0.10$ & $\leq 0.10$ & $\leq 0.10$ & $1.5-8.41$ & $6.26-11.45$ \\
\hline Stigmastadiene content in OVOO & $\leq 0.10^{\mathrm{a}}$ & $\leq 0.15$ & (b) & (b) & (b) & (b) & $(2.84-3.00)^{c}$ & $(6.86-7.85)^{\mathrm{C}}$ \\
\hline Stigmastadiene content in LVOO & $\leq 0.50$ & n.i. & & & & & & \\
\hline
\end{tabular}

Note: EVOO, extra-virgin olive oil; VOO, virgin olive oil; OVOO, ordinary virgin olive oil; LVOO, lampante virgin olive oil; ${ }^{\text {, }}$, ordinary virgin olive oil is not a category defined by European Union regulation; ${ }^{b}$, ordinary virgin olive oil is not a category defined in this international regulatory body; ${ }^{\mathrm{C}}$, range of precision values for R1 sterene ratio (COI/T.20/Doc. no. 16/Rev. 1); n.i., not indicated (there is no value specified for this parameter/category). RSDr $(\%)$, relative standard deviation for repeatability, RSD $(\%)$, relative standard deviation for reproducibility. A range is shown since the value can vary between different categories of olive and olive-pomace oils.

the calculation of ECN42, samples are always firstly purified through a silica gel solid-phase extraction cartridge. With the aim of improving the resolution of chromatographic peaks, and hence the improvement of analytical quality parameters, IOC supports another method using propionitrile as solvent in the determination of TAGs by HPLC. The results shown in Table 6 for propionitrile solvent indicate that the maximum value for repeatability matches the maximum value for reproducibility, thus an additional study could be suggested to revise and update these values.

\subsubsection{Determination of the content in stigmastadienes}

The determination of stigmasta-3,5-diene meant an inflection point in the fight against olive oil adulteration as it allows detecting the presence of refined vegetable oils (olive, olive-pomace, oils from sunflower, soybean, palm, etc.) in virgin olive oil at low concentrations since virgin olive oils and crude olive-pomace oil do not have this hydrocarbon. The last revised method - COI/T.20/Doc. No 11/Rev. 2 (2001) - consists of four steps: (i) saponification, (ii) separation of unsaponifiable matter with hexane, (iii) separation of steroidal hydrocarbon fraction by column chromatography on silica gel, and (iv) analysis by gas chromatography.

The method has undoubtedly led to greater success in the fight against adulteration over the years, but it is equally true that fraudsters have not stopped in their attempt to invalidate the usefulness of official methods to which this method has not been immune. Thus, the detection of refined vegetable oils previously desterolized in refined olive oils was solved by including the quantification of sterenes (campestadienes and stigmastadienes) in accordance with the IOC method COI/T.20/Doc. No 16/Rev. 1 (2001). This determination is based on the isolation of unsaponifiable matter, separation of the fraction of sterenes with silica gel chromatographic column impregnated with silver nitrate, and analysis by capillary GC. The critical part of this determination is the optimization of the volumes used to extract each fraction (three different fractions are extracted from the silica gel column). There is no reference to a similar method to determine sterenes in the other regulations.

Furthermore, the method of sterenes is only applied to the quantification of stigmastadiene if the concentration is higher than $4 \mathrm{mg} / \mathrm{kg}$. With lower concentrations $(0.01-4 \mathrm{mg} / \mathrm{kg})$ the IOC method for the "determination of the stigmastadiene content" (COI/T.20/Doc. no. 11/Rev. 2 2001) should be used.

The IOC and EU recently lowered the limit for stigmastadiene from 0.1 to 0.05 due to modern analytical instruments having higher sensitivity today. This change is responsible for disagreements with other regulations as shown in Table 7. This table also shows excellent values of precision (repeatability and reproducibility) as expected from a method with a strong scientific and analytical support (Lanzón, 1990) and an empirical validation with thousands of samples (Aparicio et al., 1991).

\subsubsection{Determination of the content of 2-glyceryl monopalmitate}

The content of 2-glyceryl monopalmitate by means of the determination of the percentage of palmitic acid at the 2-position of the triacylglyerols is used to detect re-esterified oils in olive oils. The IOC method - COI/T.20/Doc. No. 23 (2006) - is based on three basic steps: (i) neutralization of the sample because the $\mathrm{pH}$ is important for the activity of the pancreatic lipase; (ii) reaction with the pancreatic lipase leads to a partial hydrolysis specific to positions 1 and 3 of the triacylglycerol; and (iii) 2-monoacylglycerol, product of the reaction, is silanized and analysed by gas chromatography.

The method, however, has the drawbacks of being lengthy and tedious, and despite being recent enough, it already calls for useful tips such as:

- When sample acidity is $>3 \%$, the oil has to be previously neutralized. 
- The activity of the pancreatic lipase depends on the $\mathrm{pH}$, which should be adjusted to 8.3.

- The lipase pancreatic is not stable and may lose activity easily.

- A large broad solvent front, low repeatability and tailing peaks are the major drawbacks of on-column injections.

Table 8 shows the maximum admitted percentages of 2-glycerylmonopalmytate ( $\% 2 \mathrm{P})$ for the different categories of olive and olive-pomace oils. In the case of the standard of Codex Alimentarius, it is established that the saturated fatty acids at the 2-position in the triglyceride (sum of palmitic \& stearic acids) has to meet the following maximum levels: (i) $1.5 \%$ for EVOO and VOO; (ii) $1.8 \%$ for ROO and OO+; and (iii) $2.2 \%$ for ROPO and OO+. The small differences between minimum and maximum values in reproducibility seem to show unsolved problems in peak quantification.

\subsubsection{Determination of free acidity}

The content of the free fatty acids $(\% \mathrm{~m} / \mathrm{m})$ expressed in oleic acid, determined by the method COI/T.20/Doc. No 34 (November 2015), is used to classify the categories of olive oils. The sample is dissolved in diethyl ether/ethanol (95\%) 1:1 (v/v) and free fatty acids present in the sample are titrated using an ethanolic solution of potassium hydroxide. In order to carry out the analysis, the acid value should be previously estimated to decide the amount of sample used for the analysis.

There are changes that improve the results, such as the amount of sample that could be reduced to half $(0.5 \mathrm{~g}$ instead of $1.0 \mathrm{~g})$ when the acidity of the oil is expected to be high ( $7.5 \%$ or more), and alternative solvents, such as ethanol:water (1:1), also help in getting more amicable procedures.

Table 9 shows the differences among the international regulatory bodies. The differences are based on an attempt to lower the values in some categories, and the strictest norm is that coming from California. Furthermore, there is a unanimous difference with respect to IOC in the free acidity of LVOO. The precision values are good (maximum $\mathrm{RSD}$ is $5.3 \%$ ).

Free fatty acids can be determined with non-targeted techniques based on vibrational spectroscopy that offers the alternative of applying NIR. A calibration with samples of the same cultivar is mandatory, which diminishes its expectations. An alternative

TABLE 8. Limit values of 2-glycerylmonopalmytate (2P, expressed as percentage) content for all olive oil categories according to IOC, and differences found in other international regulations with respect to IOC values. Blank cells mean that no difference is observed compared with IOC standard. Values of analytical parameters (repeatability and reproducibility) extracted from the IOC methods are also given

\begin{tabular}{|c|c|c|c|c|c|c|c|c|}
\hline Parameter & IOC/EU & $\begin{array}{c}\text { Codex } \\
\text { Alimentarius } \\
\end{array}$ & USA & $\begin{array}{c}\text { California } \\
\text { (USA) }\end{array}$ & Australia & South Africa & $\mathrm{RSD}_{\mathrm{r}}(\%)$ & $\mathrm{RSD}_{\mathrm{R}}(\%)$ \\
\hline$\% 2 \mathrm{P}$ in $\mathrm{VOO}$ & $\begin{array}{c}\leq 0.9 \\
\text { (If } \mathrm{C} 16: 0 \leq 14.0 \% \text { ) } \\
\leq 1.0 \\
\text { (If } \mathrm{C} 16: 0>14.0 \% \text { ) }\end{array}$ & $\leq 1.5^{\mathrm{a}}$ & & n.i. & $\leq 1.5$ & $\leq 1.5$ & & \\
\hline$\% 2 \mathrm{P}$ in $\mathrm{OO}+$ & $\begin{array}{c}\leq 0.9 \\
\text { (If } \mathrm{C} 16: 0 \leq 14.0 \% \text { ) } \\
\leq 1.0 \\
\text { (If } \mathrm{C} 16: 0>14.0 \% \text { ) }\end{array}$ & $\leq 1.8^{\mathrm{a}}$ & & $\leq 1.8$ & $\leq 1.8$ & $\leq 1.8$ & & \\
\hline$\% 2 \mathrm{P}$ in $\mathrm{LVOO}$ & $\begin{array}{c}\leq 0.9 \\
\text { (If } \mathrm{C} 16: 0 \leq 14.0 \% \text { ) } \\
\leq 1.1 \\
\text { (If } \mathrm{C} 16: 0>14.0 \% \text { ) }\end{array}$ & n.i. & & n.i. & $\leq 1.5$ & $\leq 1.5$ & $1.95-8.91$ & $10.17-12.66$ \\
\hline$\% 2 \mathrm{P}$ in $\mathrm{ROO}$ & $\begin{array}{c}\leq 0.9 \\
\text { (If } \mathrm{C} 16: 0 \leq 14.0 \% \text { ) } \\
\leq 1.1 \\
\text { (If } \mathrm{C} 16: 0>14.0 \% \text { ) }\end{array}$ & $\leq 1.8^{\mathrm{a}}$ & n.i. & $\leq 1.8$ & $\leq 1.8$ & $\leq 1.8$ & & \\
\hline$\% 2 \mathrm{P}$ in $\mathrm{OPO}+$ & $\leq 1.2$ & $\leq 2.2^{\mathrm{a}}$ & & n.i. & $\leq 2.2$ & $\leq 2.2$ & & \\
\hline $\begin{array}{l}\% 2 \mathrm{P} \text { in } \mathrm{COPO} \\
\text { and } \mathrm{ROPO}\end{array}$ & $\leq 1.4$ & $\begin{array}{l}\text { n.i. }{ }^{\mathrm{a}} \text { for } \\
\text { COPO } \\
\leq 2.2^{\mathrm{a}} \text { for } \\
\text { ROPO }\end{array}$ & & n.i. & $\leq 2.2$ & $\leq 2.2$ & & \\
\hline
\end{tabular}

Note: edible virgin olive oil, includes EVOO, VOO and OVOO; EVOO, extra-virgin olive oil; VOO, virgin olive oil; OVOO, ordinary virgin olive oil; LVOO, lampante virgin olive oil; ROO, refined olive oil; $\mathrm{OO}+$, olive oil (mix of virgin and refined olive oils); $\mathrm{COPO}$, crude olive-pomace oil; ROPO, refined pomace oil; OPO+, pomace oil (mix of refined pomace oil and virgin olive oil); n.i., not indicated (there is no value specified for this parameter/category). RSDr (\%), relative standard deviation for repeatability, $\mathrm{RSD}_{\mathrm{R}}(\%)$, relative standard deviation for reproducibility. A range is shown since the value can vary between different categories of olive and olivepomace oils. ". This limit is referred as "Saturated fatty acids at the 2-position in the triglyceride (sum of palmitic \& stearic acids)" in Codex Alimentarius. 
TABLE 9. Limit values of free acidity ( $\%$ ) for all the olive oil categories according to IOC, and differences found in other international regulations with respect to IOC values. Blank cells mean that no difference is observed compared with IOC standard Values of analytical parameters (repeatability and reproducibility) extracted from the IOC methods are also given

\begin{tabular}{|c|c|c|c|c|c|c|c|c|c|}
\hline Parameter & IOC & $\begin{array}{c}\text { Codex } \\
\text { Alimentarius }\end{array}$ & $\mathbf{E U}$ & USA & $\begin{array}{c}\text { California } \\
\text { (USA) }\end{array}$ & Australia & South Africa & $\mathrm{RSD}_{\mathrm{r}}(\%)$ & $\operatorname{RSD}_{\mathrm{R}}(\%)$ \\
\hline Free acidity in EVOO & $\leq 0.8$ & & & & $\leq 0.5$ & & & \multirow{8}{*}{$0.4-1.3$} & \multirow{8}{*}{$3.1-5.3$} \\
\hline Free acidity in VOO & $\leq 2.0$ & & & & $\leq 1.0$ & & & & \\
\hline Free acidity in OVOO & $\leq 3.3$ & & (a) & (a) & (a) & (a) & (a) & & \\
\hline Free acidity in LVOO & $>3.3$ & n.i. & $>2.0$ & $>2.0$ & $>1.0$ & $>2.0$ & $>2.0$ & & \\
\hline Free acidity in ROO & $\leq 0.3$ & & & & & & & & \\
\hline Free acidity in $\mathrm{OO}+$ & $\leq 1.0$ & & & & $\leq 0.8$ & & & & \\
\hline Free acidity in COPO & No limit & (a) & & & & & & & \\
\hline Free acidity in ROPO & $\leq 0.3$ & & & & & & & & \\
\hline
\end{tabular}

Note: EVOO, extra-virgin olive oil; VOO, virgin olive oil; OVOO, ordinary virgin olive oil; LVOO, lampante virgin olive oil; ROO, refined olive oil; $\mathrm{OO}+$, olive oil (mix of virgin and refined olive oils); COPO, crude olive-pomace oil; ROPO, refined pomace oil; $\mathrm{OPO}+$, pomace oil (mix of refined pomace oil and virgin olive oil); n.i., not indicated (there is no value specified for this parameter/ category); (a), this category is not defined by the regulatory body. RSDr (\%), relative standard deviation for repeatability, $\mathrm{RSD}_{\mathrm{R}}(\%)$, relative standard deviation for reproducibility. A range is shown since the value can vary between different categories of olive and olive-pomace oils.

is based on FTIR bands near 1745 and $1711 \mathrm{~cm}^{-1}$, which only needs a calibration with standards. An improved FTIR procedure is based on the derivatization of free fatty acids to the corresponding free fatty acid salts after reacting with sodium carbodiimide (a weak base) in methanol. The resulting salt presents a measurable spectroscopic band in a region without interference and consequently this band is very easy to measure and calibrate (Li et al., 2008).

\subsubsection{Determination of peroxide value}

The determination of peroxide value has the objective of classifying the categories of olive oils based on their peroxide value in milleq. peroxide oxygen per $\mathrm{kg} /$ oil. IOC method - COI/T.20/Doc. No 35 (July 2016) - is very similar to others supported by ISO and AOCS. In general, the sample is dissolved in acetic acid and chloroform and treated with potassium iodide. The liberated iodine is titrated with a standardized sodium thiosulphate solution. In order to carry out the analysis, the peroxide value should be previously estimated to determine the amount of sample used for the analysis.

The methods for determining peroxide value are laborious, time consuming, require the use of organic solvents and their accuracy depends strongly on the experience of the analyst. The use of more amicable solvents would be interesting if they do not perturb the interpretation of the results, although the analyst should have experience in the chosen solvent. The alternative can come from vibrational spectroscopy since the FTIR band associated with $\mathrm{ROOH}$ group is well determined.

Table 10 shows that there are not special disagreements between the standards other than the lack of definition for ordinary category.

\subsubsection{Determination of the absorbency in ultra-violet}

The method COI/T.20/Doc. No 19/Rev. 3, (February 2015) describes a procedure for determining the presence of conjugated diene and triene systems resulting from oxidation processes and/or refining practices. Thus, absorbency in ultra-violet provides information on the quality of a fat, its state of preservation and changes due to technological processes.

The procedure is easy as it only requires dissolving the sample in isooctane to measure the absorbance at $232 \mathrm{~nm}$ and $268 \mathrm{~nm}$ and in cyclohexane to measure the absorbance at $232 \mathrm{~nm}$ and $270 \mathrm{~nm}$. The specific extinctions are calculated for a concentration of $1 \% \mathrm{w} / \mathrm{v}$ in a $10 \mathrm{~mm}$ cell. New instrumentation has better characterized the exact wavelengths at which the conjugated dienes and trienes absorb when using isooctane and cyclohexane.

Table 11 shows that the trade standards of IOC and EU regulation are the only ones that include the absorption for both K270 and K268 depending on the solvent that is used. On the other hand, there are noticeable differences in the lampante, refined and olive oil categories.

\subsubsection{Determination of alkyl esters}

The method COI/T.20/Doc. No 28. Rev.1 (2010) describes a procedure for determining the content of the even numbered carbon atoms of individual waxes, from $\mathrm{C} 40$ to $\mathrm{C} 46$, and the content of the even numbered carbon atoms of the ethyl and methyl esters, $\mathrm{C} 16$ and $\mathrm{C} 18$. The information from the method is used as a quality parameter for extra virgin olive oil (FAEEs) and to detect mixtures of extra 
TABLE 10. Limit values of peroxide value (PV, expressed as meq. O2/kg) for all the olive oil categories according to IOC, and differences found in other international regulations with respect to IOC values. Blank cells mean that no difference is observed compared with IOC standard. Values of analytical parameters (repeatability and reproducibility) extracted from the IOC methods are also given

\begin{tabular}{|c|c|c|c|c|c|c|c|c|c|}
\hline Parameter & IOC & $\begin{array}{c}\text { Codex } \\
\text { Alimentarius }\end{array}$ & $\mathbf{E U}$ & USA & $\begin{array}{l}\text { California } \\
\text { (USA) }\end{array}$ & Australia & South Africa & $\operatorname{RSD}_{\mathrm{r}}(\%)$ & $\operatorname{RSD}_{\mathrm{R}}(\%)$ \\
\hline $\mathrm{PV}$ in $\mathrm{EVOO}$ & $\leq 20.0$ & & & & $\leq 15.0$ & & & & \\
\hline $\mathrm{PV}$ in VOO & $\leq 20.0$ & & & & & & & & \\
\hline $\mathrm{PV}$ in $\mathrm{OVOO}$ & $\leq 20.0$ & & (a) & (a) & (a) & (a) & (a) & & \\
\hline $\mathrm{PV}$ in LVOO & No limit & (a) & $>20.0$ & $>20.0$ & $>20.0$ & $>20.0$ & $>20.0$ & & \\
\hline $\mathrm{PV}$ in $\mathrm{ROO}$ & $\leq 5.0$ & & & & & & & $0.8-3.4$ & $5.7-13.8$ \\
\hline $\mathrm{PV}$ in $\mathrm{OO}+$ & $\leq 15.0$ & & & & & & & & \\
\hline $\mathrm{PV}$ in $\mathrm{COPO}$ & No limit & (a) & & & & & & & \\
\hline $\mathrm{PV}$ in $\mathrm{ROPO}$ & $\leq 5.0$ & & & & & & & & \\
\hline $\mathrm{PV}$ in $\mathrm{OPO}+$ & $\leq 15.0$ & & & & & & & & \\
\hline
\end{tabular}

Note: EVOO, extra-virgin olive oil; VOO, virgin olive oil; OVOO, ordinary virgin olive oil; LVOO, lampante virgin olive oil; ROO, refined olive oil; $\mathrm{OO}+$, olive oil (mix of virgin and refined olive oils); COPO, crude olive-pomace oil; ROPO, refined pomace oil; $\mathrm{OPO}+$, pomace oil (mix of refined pomace oil and virgin olive oil); n.i., not indicated (there is no value specified for this parameter/ category); (a), this category is not defined by the regulatory body. RSDr (\%), relative standard deviation for repeatability, $\mathrm{RSD}_{\mathrm{R}}(\%)$, relative standard deviation for reproducibility. A range is shown since the value can vary between different categories of olive and olive-pomace oils.

virgin olive oils with lower quality olive oils (VOO, OVOO, LVOO and some deodorized oils). It is not a complicate procedure in two steps: (i) separation of the fraction of interest by column chromatography on hydrated silica gel, and (ii) the obtained fraction is analyzed by gas chromatography. The method was improved in COI/T.20/Doc. No 31 (November 2012) and is still on provisional approval, although the RSD values are higher (Table 12).

The presence of the ethyl esters of fatty acids (FAEEs) seems to indicate that olive oil could have been obtained from unhealthy olives when harvested or because of inadequate processing of olives. However, the relationship of fatty acid alkyl esters with EVOO sensory quality is casual or apparently causal (Aparicio et al., 2012). The proposal of FAEEs as markers of the presence of soft-deodorized oils in EVOOs is unclear as well.

Table 12 shows that this parameter is only specified in the IOC standard and European regulations and it is not mentioned in the rest of documents. The maximum percentage of reproducibility $(79.88 \%)$ suggests the need for further research to keep improving and examining this method and to avoid possible false positives/negatives with the consequence that it has for the olive oil sector.

\subsubsection{Determination of pyropheophytins}

There is no IOC method and the only official method is the ISO 29841 although the analyst can apply it with two options, both using reverse-phase solid-phase extraction (RP-SPE). The first option elutes with petroleum ether $\left(40-60{ }^{\circ} \mathrm{C}\right)$ while the second with petroleum ether $\left(40-60{ }^{\circ} \mathrm{C}\right)$ : ethyl ether
(9:1) for removing the lipids. A critical point in both methods is the collection of the analytes in $0.2-0.3$ $\mathrm{mL}$ of acetone which is used in both methods. The high volatility of acetone suggests making the injection in the HPLC instrument as rapid as possible. The alternative is a method (Gallardo-Guerrero et al., 2005) that gives information on individual pigments but it is tedious for the rapid control demanded by the olive oil sector.

The increment in the content of pyropheophytins (PPP) is associated with the presence of energy (either source of temperature or light) during the shelf life of virgin olive oil. The degradation of pheophytins to pyropheophytins has driven some researchers to think that this information could be of interest for, initially, detecting the presence of soft deodorized virgin olive oil in extra virgin ones. More recently, the presence of PPPs has been associated with freshness about which there is an interesting discussion in Aparicio-Ruiz et al. (2014). Despite the advantages of PPP for exclusively determining an inadequate EVOO storage from olive mill to consumer's kitchen, Californian, Australian and South African bodies have assigned PPP the role of freshness marker for extra virgin olive oils.

Table 13 shows the maximum percentage of PPP $(17 \%)$ in EVOO according to Australian, Californian and South African regulations. Although the relationship between sensory quality and PPP is under discussion in the scientific fora because there is no causal relationship between them, there is no doubt that the \%PPP increases over time, mostly due to the effect of temperature, and in lesser measure, to light, which means that it is a good marker of adequate or inadequate storage of EVOO bottles (vessels) during 
TABLE 11. Limit values of UV absorption for all the olive oil categories according to IOC, and differences found in other international regulations with respect to IOC values. Blank cells mean that no difference is observed compared with IOC standard. Values of analytical parameters (repeatability and reproducibility) extracted from the IOC methods are also given

\begin{tabular}{|c|c|c|c|c|c|c|c|c|c|}
\hline Category & IOC & $\begin{array}{c}\text { Codex } \\
\text { Alimentarius } \\
\end{array}$ & $\mathbf{E U}$ & USA & $\begin{array}{c}\text { California } \\
\text { (USA) }\end{array}$ & Australia & South Africa & $\mathrm{RSD}_{\mathrm{r}}(\%)$ & $\mathrm{RSD}_{\mathrm{R}}(\%)$ \\
\hline EVOO & $\begin{array}{l}\mathrm{K} 270 / \mathrm{K} 268 \\
\leq 0.22 \\
\Delta \mathrm{k} \leq 0.01 \\
\mathrm{~K} 232 \leq 2.50\end{array}$ & $\begin{array}{l}\text { K232 } \\
\text { n.i. }\end{array}$ & & & $\begin{array}{l}\mathrm{K} 270 \leq 0.22 \\
\Delta \mathrm{k} \leq 0.01 \\
\mathrm{~K} 232 \leq 2.40\end{array}$ & & & & \\
\hline VOO & $\begin{array}{l}\mathrm{K} 270 / \mathrm{K} 268 \\
\leq 0.25 \\
\Delta \mathrm{k} \leq 0.01 \\
\mathrm{~K} 232 \leq 2.60\end{array}$ & $\begin{array}{l}\text { K232 } \\
\text { n.i. }\end{array}$ & & & & & & & \\
\hline OVOO & $\begin{array}{l}\mathrm{K} 270 / \mathrm{K} 268 \\
\leq 0.30 \\
\Delta \mathrm{k} \leq 0.01\end{array}$ & & (a) & (a) & (a) & (a) & (a) & $(0.41-1.47)^{\mathrm{b}}$ & $(2.46-5.48)^{\mathrm{b}}$ \\
\hline LVOO & & (a) & & & $\begin{array}{l}\mathrm{K} 270>0.25 \\
\Delta \mathrm{k} \leq|0.01| \\
\mathrm{K} 232>2.60\end{array}$ & $\begin{array}{l}\mathrm{K} 270>0.25 \\
\Delta \mathrm{k}>|0.01| \\
\mathrm{K} 232>2.60\end{array}$ & $\begin{array}{l}\mathrm{K} 270>0.25 \\
\Delta \mathrm{k}>|0.01| \\
\mathrm{K} 232>2.60\end{array}$ & $\begin{array}{l}(1.02-1.42)^{\mathrm{c}} \\
(1.10-3.96)^{\mathrm{d}}\end{array}$ & $\begin{array}{l}(2.81-3.95)^{\mathrm{c}} \\
(2.59-8.00)^{\mathrm{d}}\end{array}$ \\
\hline ROO & $\begin{array}{l}\mathrm{K} 270 / \mathrm{K} 268 \\
\leq 1.25 \\
\Delta \mathrm{k} \leq 0.16\end{array}$ & $\begin{array}{l}\mathrm{K} 270 \leq 1.10 \\
\Delta \mathrm{k} \leq 0.16\end{array}$ & & $\begin{array}{l}\mathrm{K} 270 \leq 1.10 \\
\Delta \mathrm{k} \leq 0.16\end{array}$ & $\begin{array}{l}\mathrm{K} 270 \leq 1.10 \\
\Delta \mathrm{k} \leq|0.16|\end{array}$ & $\begin{array}{l}\mathrm{K} 270 \leq 1.10 \\
\Delta \mathrm{k} \leq 0.16\end{array}$ & $\begin{array}{l}\mathrm{K} 270 \leq 1.10 \\
\Delta \mathrm{k} \leq 0.16\end{array}$ & $\begin{array}{l}(0.92-4.02)^{\mathrm{e}} \\
(1.09-28.90)^{\mathrm{f}}\end{array}$ & $\begin{array}{l}(2.37-8.51)^{\mathrm{e}} \\
(5.06-147.51)^{\mathrm{f}}\end{array}$ \\
\hline $\mathrm{OO}+$ & $\begin{array}{l}\mathrm{K} 270 / \mathrm{K} 268 \\
\leq 1.15 \\
\Delta \mathrm{k} \leq 0.15\end{array}$ & $\begin{array}{l}\mathrm{K} 270 \leq 0.90 \\
\Delta \mathrm{k} \leq 0.15\end{array}$ & & $\begin{array}{l}\mathrm{K} 270 \leq 0.90 \\
\Delta \mathrm{k} \leq 0.15\end{array}$ & $\begin{array}{l}\mathrm{K} 270 \leq 0.90 \\
\Delta \mathrm{k} \leq|0.15|\end{array}$ & $\begin{array}{l}\mathrm{K} 270 \leq 0.90 \\
\Delta \mathrm{k} \leq|0.15|\end{array}$ & $\begin{array}{l}\mathrm{K} 270 \leq 0.90 \\
\Delta \mathrm{k} \leq|0.15|\end{array}$ & $(1.65-121.08)^{\mathrm{g}}$ & $(10.00-234.77)^{\mathrm{g}}$ \\
\hline \multicolumn{10}{|l|}{ COPO } \\
\hline ROPO & $\begin{array}{l}\mathrm{K} 270 / \mathrm{K} 268 \\
\leq 2.0 \\
\Delta \mathrm{k} \leq 0.20\end{array}$ & & & & $\begin{array}{l}\mathrm{K} 270 \mathrm{~K} \leq 2.0 \\
\Delta \mathrm{k} \leq|0.20|\end{array}$ & & & & \\
\hline $\mathrm{OPO}+$ & $\begin{array}{l}\mathrm{K} 270 / \mathrm{K} 268 \\
\leq 1.70 \\
\Delta \mathrm{k} \leq 0.18\end{array}$ & & & & $\begin{array}{l}\mathrm{K} 270 \leq 1.70 \\
\Delta \mathrm{k} \leq|0.18|\end{array}$ & & & & \\
\hline
\end{tabular}

Note: EVOO, extra-virgin olive oil; VOO, virgin olive oil; OVOO, ordinary virgin olive oil; LVOO, lampante virgin olive oil; ROO, refined olive oil; OO+, olive oil (mix of virgin and refined olive oils); COPO, crude olive-pomace oil; ROPO, refined pomace oil; OPO+, pomace oil (mix of refined pomace oil and virgin olive oil); n.i., not indicated (there is no value specified for this parameter/category); (a), this category is not defined by the regulatory body. RSDr (\%), relative standard deviation for repeatability, RSDR (\%), relative standard deviation for reproducibility. A range is shown since the value can vary between different categories of olive and olive-pomace oils. , UV extinction at $232 \mathrm{~nm}$ in isooctane; ${ }^{\mathrm{c}}$, UV extinction at $232 \mathrm{~nm}$ in cyclohexane; ${ }^{\mathrm{d}}$, UV extinction at $268 \mathrm{~nm}$ in isooctane; ${ }^{\mathrm{e}}$, UV extinction at $270 \mathrm{~nm}$ in cyclohexane; ${ }^{\circ}$, variation of the specific extinction coefficient K at $270 \pm 4 \mathrm{~nm}$ in cyclohexane; ${ }^{\mathrm{g}}$, variation of the specific extinction coefficient $\mathrm{K}$ at $270 \pm 4 \mathrm{~nm}$ in isooctane.

TABLE 12. Limit values of fatty acid ethyl esters (FAEEs) $(\mathrm{mg} / \mathrm{kg}$ ) for extra-virgin olive oil category, and differences found in other international regulations with respect to IOC values. Values of analytical parameters (repeatability and reproducibility) extracted from the IOC methods are also given

\begin{tabular}{lcccccc|cc}
\hline Parameter & IOC/EU & $\begin{array}{c}\text { Codex } \\
\text { Alimentarius }\end{array}$ & USA & California (USA) & Australia & $\begin{array}{c}\text { South } \\
\text { Africa }\end{array}$ & RSD $_{\mathbf{r}}(\%)$ & RSD $_{\mathbf{R}}(\%)$ \\
\hline $\begin{array}{l}\text { FAEEs in } \\
\text { EVOO }\end{array}$ & $\leq 35$ & n.i. & n.i. & n.i. & n.i. & n.i. & $\begin{array}{c}(1.0-14.8)^{\mathrm{a}} \\
(2.41-28.83)^{\mathrm{b}}\end{array}$ & $\begin{array}{c}(10.1-46.5)^{\mathrm{a}} \\
(11.08-79.88)^{\mathrm{b}}\end{array}$ \\
\hline
\end{tabular}

Note: EVOO, extra-virgin olive oil; n.i., not indicated (there is no value specified for this parameter/category). RSDr (\%), relative standard deviation for repeatability, $\operatorname{RSD}_{\mathrm{R}}(\%)$, relative standard deviation for reproducibility ${ }^{\mathrm{a}}$, COI/T.20/Doc. No 28. Rev.1; , COI/T.20/Doc. No 31.

TABLE 13. Limit values of pyropheophytin a (PPP) for extra-virgin olive oil category, and differences found in other international regulations with respect to IOC values

\begin{tabular}{lccccccc|cc}
\hline Parameter & IOC & EU & $\begin{array}{c}\text { Codex } \\
\text { Alimentarius }\end{array}$ & USA & $\begin{array}{c}\text { California } \\
\text { (USA) }\end{array}$ & Australia & $\begin{array}{c}\text { South } \\
\text { Africa }\end{array}$ & RSD $_{\mathbf{r}}(\%)$ & RSD $_{\mathbf{R}}(\%)$ \\
\hline PPP in EVOO & n.i. & n.i. & n.i. & n.i. & $\leq 17$ & $\leq 17$ & $\leq 17$ & $1.01-3.05$ & $2.21-8.56$ \\
\hline
\end{tabular}

Note: EVOO, extra-virgin olive oil; n.i., not indicated (there is no value specified for this parameter/category). 
TABLE 14. Maximum accepted percentages of moisture and volatile matter (\%) for olive oil categories, and differences found in other international regulations with respect to IOC values. Blank cells mean that no difference is observed compared with IOC standard

\begin{tabular}{llcccccc}
\hline Category & IOC & $\begin{array}{c}\text { Codex } \\
\text { Alimentarius }\end{array}$ & EU & USA & $\begin{array}{c}\text { California } \\
\text { (USA) }\end{array}$ & Australia & $\begin{array}{c}\text { South } \\
\text { Africa }\end{array}$ \\
\hline EVOO & $\leq 0.2$ & & n.i. & & & & \\
VOO & $\leq 0.2$ & & n.i. & & & & \\
OVOO & $\leq 0.2$ & & (a) & (a) & (a) & (a) & (a) \\
LVOO & $\leq 0.3$ & (a) & n.i. & n.i. & & & \\
ROO & $\leq 0.1$ & & n.i. & & & \\
OO+ & $\leq 0.1$ & & n.i. & & & \\
COPO & $\leq 1.5$ & (a) & n.i. & & & \\
ROPO & $\leq 0.1$ & & n.i. & & & \\
OPO+ & $\leq 0.1$ & & n.i. & & & \\
\hline
\end{tabular}

Note: EVOO, extra-virgin olive oil; VOO, virgin olive oil; OVOO, ordinary virgin olive oil; LVOO, lampante virgin olive oil; ROO, refined olive oil; $\mathrm{OO}+$, olive oil (mix of virgin and refined olive oils); COPO, crude olive-pomace oil; ROPO, refined pomace oil; OPO+, pomace oil (mix of refined pomace oil and virgin olive oil); n.i., not indicated (there is no value specified for this parameter/category). (a), this category is not defined by the regulatory body. RSDr (\%), relative standard deviation for repeatability, $\mathrm{RSD}_{\mathrm{R}}(\%)$, relative standard deviation for reproducibility.

the transporting step and on supermarket shelves. As IOC does not recognise any importance to PPP in controlling EVOO quality during its storage period from picking olives to consumer's kitchen, the analytical quality parameters have been collected from Gertz and Fiebig (2006) whose results are good enough.

\subsubsection{Determination of the moisture and volatile matter}

There is no IOC method as it refers to ISO 662 which describes a gravimetric method for determining the content of water and volatile matter in the oil. In the method, the sample is heated at $105^{\circ} \mathrm{C}$ in a sand-bath until moisture and volatile matter are completely removed. It can be underlined that high moisture may have a negative effect on the performance of other methods, and besides it is often regarded as a minor method that has not undergone significant improvements.

In the latest regulations of the European Union, moisture is not mentioned as a relevant parameter. On the other hand, Table 14 shows that there are no disagreements among international regulatory bodies in this parameter except that some regulations do not define ordinary virgin olive oil (OVOO), lampante virgin olive oil (LVOO) and crude olive-pomace oil (COPO). There are no values for analytical quality parameters associated with this method.

\subsubsection{Determination of unsaponifiable matter}

There is no particular IOC method but it refers to ISO (ISO 3596 - method using diethyl ether extraction - and ISO 18609 - method using hexane extraction) and AOCS (AOCS Ca 6b-53) whose procedures determine the fraction of the oil that fails to react with soda and potassium hydroxide to produce soaps and remains soluble in classic solvents (e.g., hexane, petroleum ether, diethyl ether) after saponification. The results should be expressed in $g$ of unsaponifiable matter per $\mathrm{kg} / \mathrm{oil}$.

The methods, in general, present some problems because of the lack of accuracy and precision in the results. Problems that can produce a low precision in the results are soap hydrolysis, loss of unsaponifiable matter during solvent drying, evaporation and incomplete saponification. Other problems of precision partially come from the impossibility of extracting all of the unsaponifiable matter and the formation of emulsions due to a too vigorous shaking in the liquid-liquid extraction. Thus, it has been suggested adding small quantities of ethanol to destroy the emulsions.

If soaps pass into the solvent (preferred diethyl ether) together with the unsaponifiable matter, a recommended action is to separate the soaps by washing the ether extract with an aqueous solution of sodium hydroxide, which can provoke soap hydrolysis and liberate acids.

Another problem that sometimes occurs is an incomplete saponification, which is a source of error. If an incomplete saponification occurs, the whole method has to be applied again with the unsaponifiable residue containing the non-saponified segment.

Table 15 shows how the values for unsaponifiable matter for IOC agree with the European Union, USA and Codex Alimentarius. However, there is no reference to the unsaponifiable matter in the Californian, Australian and South African 
TABLE 15. Maximum values of unsaponifiable matter ( $\mathrm{g}$ of unsaponifiable matter per $\mathrm{kg} / \mathrm{oil}$ ) in olive oil and olive pomace oil, and differences found in other international regulations with respect to IOC values. Blank cells mean that no difference is observed compared with IOC standard

\begin{tabular}{|c|c|c|c|c|c|c|c|}
\hline Parameter & IOC & $\begin{array}{c}\text { Codex } \\
\text { Alimentarius }\end{array}$ & $\mathbf{E U}$ & USA & $\begin{array}{l}\text { California } \\
\text { (USA) }\end{array}$ & Australia & South Africa \\
\hline Unsaponifiable matter in olive oils & $\leq 15$ & & n.i. & & n.i. & n.i. & n.i. \\
\hline Unsaponifiable matter in olive pomace oils & $\leq 30$ & & n.i. & & n.i. & n.i. & n.i. \\
\hline
\end{tabular}

Note: n.i., not indicated (there is no value specified for this parameter/category).

TABLE 16. Values (maximum, minimum or range) of the medians of defects (Md) and fruitiness (Mf) for olive oil categories (virgin, refined, olive oil, refined olive pomace oil and olive pomace oil), and differences found in other international regulations with respect to IOC values. Blank cells mean that no difference is observed compared with IOC standard

\begin{tabular}{|c|c|c|c|c|c|c|c|}
\hline Category & IOC & $\begin{array}{c}\text { Codex } \\
\text { Alimentarius }\end{array}$ & $\mathbf{E U}$ & USA & $\begin{array}{l}\text { California } \\
\text { (USA) }\end{array}$ & Australia & South Africa \\
\hline EVOO & $\begin{array}{l}\mathrm{Md}=0 \\
\mathrm{Mf}>0\end{array}$ & & & & & & \\
\hline VOO & $\begin{array}{l}0<\operatorname{Md} \leq 3.5 \\
\operatorname{Mf}>0\end{array}$ & $\begin{array}{l}0<\mathrm{Md} \leq 2.5 \\
\mathrm{Mf}>0\end{array}$ & & $\begin{array}{l}0<\mathrm{Md} \leq 2.5 \\
\mathrm{Mf}>0\end{array}$ & $\begin{array}{l}0<\mathrm{Md} \leq 2.5 \\
\mathrm{Mf}>0\end{array}$ & $\begin{array}{l}0<\mathrm{Md} \leq 2.5 \\
\mathrm{Mf}>0\end{array}$ & $\begin{array}{l}0<\mathrm{Md} \leq 2.5 \\
\mathrm{Mf}>0\end{array}$ \\
\hline OVOO & $\begin{array}{l}3.5<\mathrm{Me} \leq 6.0 \\
\text { or } \\
0<\mathrm{Md} \leq 3.5 \\
\mathrm{Mf}=0\end{array}$ & $\begin{array}{l}2.5<\mathrm{Me} \leq 6.0 \\
\text { or } \\
0<\mathrm{Md} \leq 2.5 \\
\mathrm{Mf}=0\end{array}$ & (a) & (a) & (a) & (a) & (a) \\
\hline LVOO & $\mathrm{Md}>6.0$ & n.i. & $\begin{array}{l}\mathrm{Md}>3.5 \\
\text { or } \\
0<\mathrm{Md} \leq 3.5 \\
\mathrm{Mf}=0\end{array}$ & $\begin{array}{l}\mathrm{Md}>2.5 \\
\text { or } \\
0<\mathrm{Md} \leq 2.5 \\
\mathrm{Mf}=0\end{array}$ & $\mathrm{Md}>2.5$ & $\mathrm{Md}>2.5$ & $\mathrm{Md}>2.5$ \\
\hline ROO & n.i. & n.i. & n.i. & n.i. & $\mathrm{Md} \leq 2.5$ & $\mathrm{Md} \leq 2.5$ & $\mathrm{Md} \leq 2.5$ \\
\hline $\mathrm{OO}+$ & n.i. & n.i. & n.i. & n.i. & $\begin{array}{l}\mathrm{Md} \leq 2.5 \\
\mathrm{Mf}>0\end{array}$ & $\begin{array}{l}\mathrm{Md} \leq 2.5 \\
\mathrm{Mf}>0\end{array}$ & $\begin{array}{l}\mathrm{Md} \leq 2.5 \\
\mathrm{Mf}>0\end{array}$ \\
\hline ROPO & n.i. & n.i. & n.i. & n.i. & $\mathrm{Md} \leq 2.5$ & $\mathrm{Md} \leq 2.5$ & $\mathrm{Md} \leq 2.5$ \\
\hline $\mathrm{OPO}+$ & n.i. & n.i. & n.i. & n.i. & $\begin{array}{l}\mathrm{Md} \leq 2.5 \\
\mathrm{Mf}>0\end{array}$ & $\begin{array}{l}\mathrm{Md} \leq 2.5 \\
\mathrm{Mf}>0\end{array}$ & $\begin{array}{l}\mathrm{Md} \leq 2.5 \\
\mathrm{Mf}>0\end{array}$ \\
\hline
\end{tabular}

Note: EVOO, extra-virgin olive oil; VOO, virgin olive oil; OVOO, ordinary virgin olive oil; LVOO, lampante virgin olive oil; ROO, refined olive oil; $\mathrm{OO}+$, olive oil (mix of virgin and refined olive oils); ROPO, refined pomace oil; OPO+, pomace oil (mix of refined pomace oil and virgin olive oil); n.i., not indicated (there is no value specified for this parameter/category). (a), this category is not defined by the regulatory body.

regulations. No values of analytical quality parameters are supplied by IOC.

\subsubsection{Determination of organoleptic characteristics}

Virgin olive oil category is widely regulated by IOC in what concerns sensory assessment. There are several methods or procedures that explain the general basic vocabulary for the sensory analysis (COI/T.20/Doc. No 4/Rev. 1, 2007): the kind of glasses for virgin olive oil tasting (COI/T.20/Doc. No 5/Rev. 1, 2007), a guide for the installation of a test room (COI/T.20/Doc. No 6/Rev.1, 2007), a guide for the selection, training and monitoring of skilled virgin olive oil tasters (COI/T.20/ Doc. No 14/Rev. 4, 2013), the method for the organoleptic assessment of virgin olive oil (COI/T.20/Doc. No 15/ Rev. 8, 2015), another method for the organoleptic assessment particularly focused on designations of origin (COI/T.20/Doc. No 22, 2005), and guidelines for the accreditation of laboratories undertaking the sensory analysis of virgin olive oils (COI/T.28/Doc. No 1, 2007).

This complete set of documents for the sensory assessment of the virgin olive category has the objective of classifying the categories (EVOO, VOO, OVOO, LVOO) based on their odor and taste exclusively. The median of defect and the median of the fruity attribute are calculated, according to Annex I of COI/T.20/Doc. No15/ Rev. 8 (Method for calculating the median and the confidence intervals), and they determine the classification of VOOs into one of the four possible categories (Table 16). It is noticeable that IOC and Codex Alimentarius are the only international regulatory bodies that define ordinary virgin olive oils (OVOO), which is an intermediate category between virgin (VOO) and lampante (LVOO) oils. On the other hand, the limit between virgin and ordinary/lampante categories is 2.5 or 
3.5 depending on the regulation. Thus, the limit was raised to 3.5 in some regulations to consider the high level of uncertainty in the classification of the boundaries of these two categories and to minimize any problem deriving from a possible poor harmonization among different panels (Angerosa and Campestre, 2013). Another source of disagreement is the fact that the Californian, Australian and South African standards also consider these values of $\mathrm{Md}$ and $\mathrm{Mf}$ for olive pomace and refined categories. Surprisingly, IOC does not provide information about the analytical quality parameters of this method.

Although the set of IOC methods for a correct sensory assessment (also so-called Panel Test) is accepted by all the international regulatory bodies, in terms of methodologies and procedures, it is in need of urgent improvements. Three of them are: (i) the development of reference materials for training and retraining of panellists as well as for panel test evaluation, improvement in the harmonization of sensory panels, improvement in the data treatment and statistics, improvement in the training step, and development of new analytical tools for supporting the sensory evaluation; (ii) better definitions of some emergent sensory descriptors as a consequence of climate change (i.e. 'frostbitten olives'); and (iii) the need of evaluating the sensory assessment with analytical parameters that are important in determining the absence/presence of any sensory defect, for example, limit of detection. In this regard, relevant issues are also the potential subjectivity, inadequate training, too high sensitivity of some assessors for some odours, and odour thresholds.

The immediate consequence of those weaknesses is that the official method is questioned by some VOO actors, because the difference between virgin and extra-virgin olive oils depends on the presence/ absence of defects, whatever their level of perception. The detection of sensory defects at a low level is one of the reasons a panel may fail sometimes. This is the case when two panel tests disagree on the presence/absence of a given sensory defect, which is enough to qualify olive oils as virgin instead of extra-virgin or vice versa. The statistics, the interpretation of results and the readability of the report have also been identified as issues to be improved upon in the sensory analysis (EC, 2015) and they are currently under discussion today.

\subsubsection{Other parameters}

Table 17 summarizes the values of other parameters related to olive oil contaminants and quality. The limit values for each olive oil category are displayed and it can conclude that Californian, Australian and South African regulations differ from the IOC trade standard in the values of "insoluble impurities in light petroleum" that are higher $(\leq 0.05 v s . \leq 0.1)$, and also that OVOO is a category defined by IOC and Codex Alimentarius exclusively.

\section{ANALYSIS OF PRECISION VALUES}

It is well known that for centuries unscrupulous traders have attempted to alter olive oil composition to maximize revenues. Although the frequency of fraudulent practices is unclear, each detected fraud has been featured as a mass media headline in various countries in recent years. It is always true that from the 1940's, olive oil trade standards covering definition and composition of the diverse designations, as displayed in this work, have meant an effective barrier against adulterations that has not been crossed by fraudsters easily. Infringement of such labelling regulations leaves traders open to severe penalties in courts. It means that analytical methods on which the legislation is based have to be validated in such a way that honest olive oil producers are protected from false incriminations as much as possible. In this context, the validation of the analytical methods by means of the calculation of their analytical quality parameters plays a crucial role in testing their performance.

A method has to produce data, from sampling to reporting, with adequate accuracy, precision, selectivity and sensitivity. However, the documents are mostly focused on evaluating the method performance with mathematically derived quality criteria related to accuracy (trueness and precision). The term "adequate precision", sometimes employed by statisticians, is vague although there will be a full agreement that $\mathrm{RSD}_{\mathrm{R}}$ values higher than $40 \%$, and even lower, are not adequate. Table 18 shows the range of $\mathrm{RSD}_{\mathrm{r}}$ and $\mathrm{RSD}_{\mathrm{R}}$ values of those IOC methods with precision higher than $15 \%$ in order to have a better vision of the matter and its current problems and suggested solutions. Table 18 also displays concentrations associated to the ring test samples in which the maximum values of $\mathrm{RSD}_{\mathrm{r}}$ and $\mathrm{RSD}_{\mathrm{R}}$ were found as well as the limit value for the analytical parameter in the latest approved trade standard, COI/T.15/NC No 3/Rev. 11 (July 2016).

The precision studies are carried out with different levels of concentration values because precision is generally dependent on analyte concentration. Furthermore, these concentration levels should cover the range of interest (Magnusson and Örnemark, 2014). The concentration ranges are selected by taking into account the concentrations of interest. In this case, these concentrations are the limits described in the latest IOC trade standard (COI/T.15/NC No 3/Rev. 11). Sometimes the selection of samples for covering all the concentrations is not an easy matter. From this viewpoint, the determination of FAMEs and trans fatty acids with COI/T.20/Doc. No 33 can require further analysis. The FAMES that are not cited in Table 18 (C16:0, 
TABLE 17. Limit values for different parameters related to olive oil quality (insoluble impurities in light petroleum, flash point and trace metals of copper and iron) and contaminants (trace of heavy metals, traces of halogenated solvents), and differences found in other international regulations with respect to IOC value. Blank cells mean that no difference is observed compared with IOC standard

\begin{tabular}{|c|c|c|c|c|c|c|c|c|}
\hline Parameter & Category & IOC & $\begin{array}{l}\text { Codex } \\
\text { Alimentarius }\end{array}$ & $\mathbf{E U}$ & USA & California (USA) & Australia & South Africa \\
\hline \multirow{9}{*}{$\begin{array}{l}\text { Insoluble impurities in } \\
\text { light petroleum }\end{array}$} & EVOO & $\leq 0.1$ & & n.i. & & & & \\
\hline & VOO & $\leq 0.1$ & & n.i. & & & & \\
\hline & OVOO & $\leq 0.1$ & & (a) & (a) & (a) & (a) & (a) \\
\hline & LVOO & $\leq 0.2$ & n.i. & n.i. & n.i. & & & \\
\hline & ROO & $\leq 0.05$ & & n.i. & & $\leq 0.1$ & $\leq 0.1$ & $\leq 0.1$ \\
\hline & $\mathrm{OO}+$ & $\leq 0.05$ & & n.i. & & $\leq 0.1$ & $\leq 0.1$ & $\leq 0.1$ \\
\hline & $\mathrm{COPO}$ & n.i. & n.i. & n.i. & n.i. & n.i. & n.i. & n.i. \\
\hline & ROPO & $\leq 0.05$ & & n.i. & & $\leq 0.1$ & $\leq 0.1$ & $\leq 0.1$ \\
\hline & $\mathrm{OPO}+$ & $\leq 0.05$ & & n.i. & & $\leq 0.1$ & $\leq 0.1$ & $\leq 0.1$ \\
\hline Flash point $\left({ }^{\circ} \mathrm{C}\right)$ & $\mathrm{COPO}$ & $\geq 120$ & n.i. & n.i. & & n.i. & n.i. & n.i. \\
\hline \multirow{9}{*}{$\begin{array}{l}\text { Trace metals of copper } \\
\text { and iron }\end{array}$} & EVOO & $\mathrm{Cu} \leq 3.0 ; \mathrm{Fe} \leq 0.1$ & & n.i. & & & & \\
\hline & VOO & $\mathrm{Cu} \leq 3.0 ; \mathrm{Fe} \leq 0.1$ & & n.i. & & & & \\
\hline & OVOO & $\mathrm{Cu} \leq 3.0 ; \mathrm{Fe} \leq 0.1$ & & (a) & (a) & (a) & (a) & (a) \\
\hline & LVOO & $\mathrm{Cu} \leq 3.0 ; \mathrm{Fe} \leq 0.1$ & n.i. & n.i. & & & & \\
\hline & ROO & $\mathrm{Cu} \leq 3.0 ; \mathrm{Fe} \leq 0.1$ & & n.i. & & & & \\
\hline & $\mathrm{OO}+$ & $\mathrm{Cu} \leq 3.0 ; \mathrm{Fe} \leq 0.1$ & & n.i. & & & & \\
\hline & $\mathrm{COPO}$ & n.i. & n.i. & n.i. & & & & \\
\hline & ROPO & $\mathrm{Cu} \leq 3.0 ; \mathrm{Fe} \leq 0.1$ & & n.i. & & & & \\
\hline & $\mathrm{OPO}+$ & $\mathrm{Cu} \leq 3.0 ; \mathrm{Fe} \leq 0.1$ & & n.i. & & & & \\
\hline Traces of heavy metals ${ }^{\mathrm{d}}$ & $\begin{array}{l}\text { All } \\
\text { categories }\end{array}$ & $\mathrm{Pb} \leq 0.1 ;$ As $\leq 0.1$ & n.i. & n.i. ${ }^{b}$ & & n.i. ${ }^{b}$ & n.i. ${ }^{b}$ & n.i. ${ }^{b}$ \\
\hline $\begin{array}{l}\text { Traces of halogenated } \\
\text { solvents }\end{array}$ & $\begin{array}{l}\text { All } \\
\text { categories }\end{array}$ & $\leq 0.1^{\mathrm{c}}$ & & n.i. ${ }^{b}$ & & & n.i. & n.i. \\
\hline
\end{tabular}

Note: EVOO, extra-virgin olive oil; VOO, virgin olive oil; OVOO, ordinary virgin olive oil; LVOO, lampante virgin olive oil; ROO, refined olive oil; $\mathrm{OO}+$, olive oil (mix of virgin and refined olive oils); COPO, crude olive-pomace oil; ROPO, refined pomace oil; OPO+, pomace oil (mix of refined pomace oil and virgin olive oil); n.i., not indicated (there is no value specified for this parameter/category). (a), this category is not defined by the regulatory body. ", should meet other food regulations; , sum of all solvents $\leq 0.2 \mathrm{mg} / \mathrm{kg}$; , in $\mathrm{mg} / \mathrm{kg}$.

C16:1, C18:0, C18:1, C18:2, C18:3, C20:0, C20:1) have a RSD and $\mathrm{RSD}_{\mathrm{R}}$ lower than $10.0 \%$ according to the information supplied in Annex C of COI/T.20/ Doc. No 33. The precision values for all the FAMEs, in particular those cited in Table 18, could be better if the samples selected covered all the possible concentrations including the established limit. That could imply selecting samples for specific fatty acids. For instance, the range of $\mathrm{C} 18: 2$ in genuine olive oils is between $2.50 \%$ and $21.00 \%$ according the latest trade standard. However, the values of samples used in the precision study varied between $7.18 \%$ and $9.66 \%$, a small range in $2.50 \%-21.00 \%$. Similar conclusions can be obtained by analyzing the values of the other fatty acids described in Annex C of COI/T.20/Doc. No 33.

The precision values for trans fatty acids also corroborate that they can be improved if other concentration levels are considered. The concentrations of $t$-C18:1 in the samples of the precision study vary between $0.0100 \%$ and $0.1173 \%$ while the limits of this parameter in olive oil categories are higher (COI/T.15/NC No 3/Rev. 11). The current precision values (pp. 14-15 of COI/T.20/Doc. No 33) have been obtained from samples with very low percentages of $t-\mathrm{C} 18: 1$ and $t-\mathrm{C} 18: 2+t-\mathrm{C} 18: 3$, which results in percentages of precision values that could be better if higher concentrations were considered. The results will be better if the detection and quantification limits for the method are determined and concentrations lower than those limits are avoided in further studies.

The analysis of the precision study for sterols centers attention on other aspects that can improve the results shown in COI/T.20/Doc. No30/Rev.1 (pp. 15-18). Some samples used for the precision study have the same or very similar concentrations (Table 18). These are the cases of Cholesterol and Brassicasterol. In the case of Cholesterol three out of 5 samples have a mean percentage of $0.13 \%$, 
TABLE 18. Range of relative standard deviation for repeatability $\left(\mathrm{RSD}_{\mathrm{r}}\right)$ and reproducibility $\left(\mathrm{RSD}_{\mathrm{R}}\right)$ expressed as percentage and the corresponding limit values describe in the IOC standard (COI/T.15/NC No 3/Rev. 11)

\begin{tabular}{|c|c|c|c|c|c|c|}
\hline & $\underset{(\min -\max )}{\text { Range } \mathrm{RSD}_{\mathrm{r}}}$ & $\underset{(\min -\max )}{\operatorname{Range} \mathrm{RSD}_{\mathrm{R}}}$ & Limit value & $\begin{array}{l}\text { Concentration } \\
\text { range of the } \\
\text { samples used in } \\
\text { validation study }\end{array}$ & $\begin{array}{l}\text { Concentration } \\
\text { values in which the } \\
\text { maximum } \text { RSD }_{\mathrm{r}} \\
\text { was obtained }\end{array}$ & $\begin{array}{c}\text { Concentration } \\
\text { values in which } \\
\text { the maximum } \\
\text { RSD }_{\mathrm{R}} \text { was } \\
\text { obtained }\end{array}$ \\
\hline Myristic acid (14:0) (\%) & $11-38$ & $32-52$ & $\leq 0.03$ & $0.009-0.0181$ & 0.01 & 0.0118 \\
\hline Behenic acid (C22:0) (\%) & $6.9-14.0$ & $8.3-17.0$ & $\leq 0.20$ & $0.111-0.185$ & 0.116 & 0.116 \\
\hline Lignoceric acid (C24:0) (\%) & $8.9-24.0$ & $19: 0-49.0$ & $\leq 0.20$ & $0.040-0.075$ & 0.049 & 0.040 \\
\hline $\mathrm{C} 18: 1 \mathrm{t}(\%)$ & $13.0-41.0$ & $48.0-100.0$ & $\leq 0.05-\leq 0.40$ & $0.0100-0.1173$ & 0.0114 & 0.0107 \\
\hline $\mathrm{C} 18: 2 \mathrm{t}(\%)$ & $24.0-70.0$ & $71.0-105.0$ & n.i. & $0.0061-0.0133$ & 0.0061 & 0.0061 \\
\hline $\mathrm{C} 18: 2 \mathrm{t}+\mathrm{C} 18: 3 \mathrm{t}(\%)$ & $24.0-115.0$ & $81.0-130.0$ & $\leq 0.05-\leq 0.35$ & $0.0054-0.0254$ & 0.0088 & 0.0088 \\
\hline Cholesterol (\%) & $7.2-18.8$ & $17.8-31.9$ & $\leq 0.5$ & $0.13^{\mathrm{a}}-0.21$ & 0.13 & 0.13 \\
\hline Brassicasterol (\%) & $2.7-32.7$ & $3.6-115.2$ & $\leq 0.1, \leq 0.2^{\mathrm{c}}$ & $0.000-1.46^{\mathrm{b}}$ & 0.05 & 0.02 \\
\hline$\Delta^{7}$-Stigmastenol (\%) & $2.6-9.5$ & $4.9-25.3$ & $\leq 0.5^{\mathrm{d}}$ & $0.27-3.52$ & 0.27 & 0.27 \\
\hline Erythrodiol + Uvaol (\%) & $1.0-15.3$ & $4.6-32.2$ & $\leq 4.5$ & $1.06-27.17$ & 1.06 & 1.06 \\
\hline$\Delta \mathrm{ECN} 42(\%)$ & $2.77-22.51^{\mathrm{e}}$ & $5.42-46.19^{f}$ & $\leq 0.2-\leq 0.6$ & $0.04-1.66$ & 0.18 & 0.18 \\
\hline $\begin{array}{l}\Delta \mathrm{ECN} 42 \text { with propionitrile } \\
(\%)\end{array}$ & $1.57-36.60$ & $11.21-36.80^{\mathrm{g}}$ & $\leq 0.2-\leq 0.6$ & $0.06-1.07$ & 0.06 & 0.10 \\
\hline FAEEs $(\mathrm{mg} / \mathrm{kg})$ & $\begin{array}{l}(1.0-14.8)^{\mathrm{h}} \\
(2.41-28.83)^{\mathrm{i}}\end{array}$ & $\begin{array}{l}(10.1-46.5)^{\mathrm{h}} \\
(11.08-79.88)^{\mathrm{i}}\end{array}$ & $\leq 35$ & $\begin{array}{c}(5.16-275.52)^{\mathrm{h}} \\
(2.98-151.25)^{\mathrm{i}}\end{array}$ & $\begin{array}{l}5.16^{\mathrm{h}} \\
4.52^{\mathrm{i}}\end{array}$ & $\begin{array}{l}5.16^{\mathrm{h}} \\
2.98^{\mathrm{i}}\end{array}$ \\
\hline
\end{tabular}

Note: n.i., not indicated (there is no value specified for this parameter/category). ${ }^{\text {a }} 3$ of the 5 samples used in the study presented the same concentration $(0.13 \%)$, being the other two 0.16 and $0.21 \% ;, 2$ of the 5 samples used in the study presented the same concentration $(0.02 \%)$, being the other three $0.000,0.05$, and $1.46 \%{ }^{\circ}{ }^{c}$, the limit of $\leq 0.2$ is only applicable to olive pomace oil (OPO); ${ }^{d}$, this value can be subjected to decision tree; ${ }^{\mathrm{e}}, 2$ of the 5 samples used in the study showed $\mathrm{RSD}_{\mathrm{r}}$ values of $82.24 \%$ and $76.11 \%$ and they were qualified as non-significant in the method description (COI/T.20/Doc. No 20/ Rev. 3); , 2 of the 5 samples used in the study showed RSD Ralues of $127.56 \%$ and $132.17 \%$ and they were qualified as non-significant in the method description (COI/T.20/Doc. No 20/ Rev. 3); ${ }^{\mathrm{g}}$, 1 of the 5 samples used in the study showed $\mathrm{RSD}_{\mathrm{R}}$ values of $78.58 \%$ and they were qualified as non-significant in the method description (COI/T.20/Doc. No 20/ Rev. 3); , determination according to COI/T.20/Doc. No 28/Rev. 1; ${ }^{1}$, determination according to COI/T.20/ Doc. No 31. Values of analytical parameters (repeatability and reproducibility) extracted from the IOC methods are also given.

where $\mathrm{RSD}_{\mathrm{R}}$ oscillates between $17.8 \%$ and $31.9 \%$. None of the samples has a percentage around 0.5 , which is the maximum for a genuine olive oil. A similar case is observed in Brassicasterol.

Table 18 shows that a genuine olive oil would have a percentage of $\Delta^{7}$-stigmastenol $\leq 0.5 \%$ but none of the samples has a percentage around this figure, the nearest is 0.27 with a $\mathrm{RSD}_{\mathrm{R}}$ of $25.3 \%$. A logarithm interpolation applied to the values given in the study (COI/ T.20/ Doc. No 30/Rev. 1) results in a $\mathrm{RSD}_{\mathrm{R}}$ of $17.5 \%$ for a concentration value of $0.5 \%$.

The precision study of the method (COI/T.20/ Doc. No 30/Rev.1) for triterpenic dialcohols produced good results. Two samples of the precision study have concentrations of 22.38 and $27.17 \mathrm{mg} / \mathrm{kg}$ while the maximum for olive oils is $4.5 \mathrm{mg} / \mathrm{kg}$ (olivepomace oils have concentrations $>4.5 \mathrm{ppm}$ ) in the latest trade standard (COI/T.15/NC No 3/Rev. 11). Thus, the RSD values for the concentrations closer to this limit are more relevant when evaluating the performance of the method.

There are two methods for quantifying the ethyl esters of fatty acids (FAEEs), COI/T.20/Doc. No 28/Rev. 1 (2010) (standard method) and COI/T.20/ Doc. No 31 (November 2012) (provisional method).
The precision study of both methods has not been carried with samples around $35 \mathrm{mg} / \mathrm{kg}$, which is the maximum amount that a genuine extra-virgin olive oil can contain. Three samples in both methods have concentrations of FAEEs more than two times the cited maximum amount and the other two samples have low enough concentrations. Thus, a solution for determining $\mathrm{RSD}_{\mathrm{R}}$ at $35 \mathrm{mg} / \mathrm{kg}$ can be a tentative logarithmic interpolation with the samples used in the precision study. Some incongruities found in the data led to ignoring one piece of data in the estimation. Thus, $\mathrm{RSD}_{\mathrm{R}}$ of $28.44 \%$ and $24.80 \%$ correspond to the samples with concentrations $21.20 \mathrm{mg} /$ $\mathrm{kg}$ and $87.02 \mathrm{mg} / \mathrm{kg}$, respectively (COI/T.20/Doc. No 31). Therefore, the latter concentration level was ignored in the estimation. The logarithmic interpolation seems to indicate that $\mathrm{RSD}_{\mathrm{R}}$ at $35 \mathrm{mg} / \mathrm{kg}$ might be approx. $28 \%$ for the official method and approx. $23 \%$ for the provisional method.

\section{CONCLUSIONS}

International regulatory bodies have designed their standards with the information supplied by the research on olive oil Chemistry. A high number 
of the parameters qualifying the diverse designations of olive oils and their limits for determining their genuineness were initially proposed by the IOC. Most of these parameters can be determined by methods and procedures developed by the IOC though there are alternatives proposed by other institutions (i.e. AOCS, ISO, IUPAC, FOSFA).

The limits for some parameters are, however, at the core of the disagreements among international regulatory bodies. The spread of olive tree orchards all over the world, when only a few decades ago they were circumscribed to Mediterranean countries, can be on the basis of the disagreement. It is known that climate conditions affect chemical and biochemical pathways that are responsible for quantitative changes in olive oil chemical composition and sometimes updates in regulations are necessary. The different institutions involved in olive oil authenticity are taking actions to change the parameters that have resulted in disagreements. A harmonization among regulation is expected from the olive oil sector and this activity has been identified as a challenge for the near future. Reducing the number of standard parameters would be beneficial for facilitating international trade as well. The harmonization could come from collaboration among regulatory bodies in order to achieve an agreement for some specific parameters that are subjected to debate.

In regards to the analytical quality parameters, the protocols for the testing methods published by the IOC include the values of precision $\left(\mathrm{RSD}_{\mathrm{r}}\right.$ and $\mathrm{RSD}_{\mathrm{R}}$ ) that help in understanding their performance. The evaluation of the methods, which are regularly examined and updated in the regulatory bodies, is a continuous activity since the analytical quality parameters can be improved, and new strategies can be proposed to identify sources of error and possible solutions. Additionally, the validation of methods is not only circumscribed to precision, and there are other parameters such as limits of detection and quantification, sensitivity, selectivity, linearity, etc., which are relevant from an analytical viewpoint. The methods have been proven efficient in the authenticity and quality control over the years, and any addition in their performance testing would turn into greater trust in the current methods on the part of the different actors in the olive oil sector.

\section{ACKNOWLEDGMENTS}

The research leading to these results has received funding from the European Union's Seventh Framework Program for research, technological development and demonstration under grant agreement No. 613688 (Food Integrity project).

\section{REFERENCES}

Angerosa F, Campestre C. 2013. Sensory Quality: Methodologies and Applications, in Aparicio R, Harwood J (Eds.) Handbook of Olive Oil. Analysis and Properties, second ed., Springer, New York, pp. 589-654. https://doi. org/10.1007/978-1-4614-7777-8 14

Aparicio R, Conte LS, Fiebig HJ. 2013. Olive oil authentication, in Aparicio R, Harwood J (Eds.) Handbook of Olive Oil. Analysis and Properties, second ed., Springer, New York, pp. 589-654. https://doi.org/10.1007/978-1-4614-7777-8_16

Aparicio R, Ferreiro L, Alonso V. 1994. Effect of climate on the chemical composition of virgin olive oil. Anal. Chim. Acta 292, 235-241. https://doi.org/10.1016/0003-2670(94)00065-4

Aparicio R, Ferreiro L, Rodríguez-Morales JL. 1991. Characterization of Andalusian virgin olive oils: SEXIA Project, in Informaciones Técnicas 13/91. Junta de Andalucía, Sevilla, Spain, pp. 1-96.

Aparicio R, Morales M.T, García-González DL. 2012. Towards new analyses of aroma and volatiles to understand sensory perception of olive oil. Eur. J. Lipid Sci. Technol. 114, 1114-1125. https://doi.org/10.1002/ejlt.201200193

Aparicio-Ruiz R, Aparicio R, García-González DL. 2014. Does "Best Before" date embody extra-virgin olive oil freshness? J. Agric. Food Chem. 62, 554-556. https://doi.org/10.1021/ jf405220d

Baeten V, Dardenne P, Aparicio R. 2001. Interpretation of Fourier transform Raman spectra of the unsaponifiable matter in a selection of edible oils. J. Agric. Food Chem. 49, 5098-5107. https://doi.org/10.1021/jf010146x

Barjol, J-L. 2013. Introduction, in Aparicio R, Harwood J (Eds.) Handbook of Olive Oil. Analysis and Properties, second ed., Springer, New York, pp. 1-17. https://doi. org/10.1007/978-1-4614-7777-8 1

Dais P. 2013. Nuclear Magnetic Resonance: Methodologies and Applications, in Aparicio R, Harwood J (Eds.) Handbook of Olive Oil. Analysis and Properties, second ed, Springer, New York, pp. 395-430. https://doi. org/10.1007/978-1-4614-7777-8_11

European Commission (EC). EC-DG-AGRI and JRC-IRMM. 2015. Workshop on sensory analysis for better quality of virgin olive oil. Newsletter, October 2015, Milan. https:// ec.europa.eu/agriculture/expo-milano-2015/cap-events/ virgin-olive-oil_en

EU, European Parliament Report on the food crisis, fraud in the food chain and the control thereof (2013/2091(INI)), Ref. A7-0434/2013, on 4.12.2013. Rapporteur: Esther de Lange.

Gallardo-Guerrero L, Gandul-Rojas B, Roca M, MínguezMosquera MI. 2005. Effect of storage on the original pigment profile of Spanish virgin olive oil. J. Am. Soc. Chem. Soc. 82, 33-39. https://doi.org/10.1007/s11746-005-1039-8

Gertz C, Fibig J-H. 2006. Pyropheophytin a - Determination of thermal degradation products of chlorophyll a in virgin olive oil. Eur. J. Lipid Sci. Technol. 108, 1062-1065. https:// doi.org/10.1002/ejlt.200600164

Lanzón A. 1990. Changed produced in the components of the unsaponifiable of olive oil as consequence of the refining process. Ph.D. Thesis, Universidad de Sevilla, Spain.

León-Camacho M, Morales MT, Aparicio R. 2013. Chromatographic methodologies: compounds for olive oil traceability issues, in Aparicio R, Harwood J (Eds.) Handbook of Olive Oil. Analysis and Properties, second ed., Springer, New York, pp. 163-217. https://doi. org/10.1007/978-1-4614-7777-8_6

Li Y, García-González DL, Yu X, van de Voort FR. 2008. Determination of free fatty acids in edible oils using a variable filter array (VFA) IR spectrometer. J. Am. Oil Chem. Soc. 85, 599-604. https://doi.org/10.1007/ s11746-008-1232-z

Magnusson B, Örnemark U. 2014. Eurachem Guide: The Fitness for Purpose of Analytical Methods - A Laboratory Guide to Method Validation and Related Topics. second Edition. Available from www.eurachem.org. 